\title{
Dopamine and Corticotropin-Releasing Factor Synergistically Alter Basolateral Amygdala-to-Medial Prefrontal Cortex Synaptic Transmission: Functional Switch after Chronic Cocaine Administration
}

\author{
Luis Orozco-Cabal, Jie Liu, Sebastian Pollandt, Kady Schmidt, Patricia Shinnick-Gallagher, and Joel P. Gallagher \\ Department of Pharmacology and Toxicology, The University of Texas Medical Branch, Galveston, Texas 77555-1031
}

\begin{abstract}
Basolateral amygdala (BLA) neurons provide a major excitatory input to medial prefrontal cortex (mPFC)-layer V pyramidal neurons. Under stressful conditions, commonly associated with chronic cocaine abuse, altered BLA-to-mPFC synaptic transmission could lead to defective emotional information processing and decision making within the $\mathrm{MPFC}$ and result in misguided and inappropriate behaviors. We examined the effects of cocaine administered chronically in vivo on EPSCs recorded from a putative BLA-mPFC pathway in vitro and their modulation by dopamine (DA), corticotropin-releasing factor (CRF), and their combination (DA plus CRF). In saline-treated animals, activation of $\mathrm{D}_{1 / 5}$ receptors depressed BLA-mPFC EPSCs, whereas $\mathrm{CRF}_{1}$ receptor activation alone had no effect on EPSCs. Activating $\mathrm{D}_{1 / 5}$ and $\mathrm{CRF}_{1}$ receptors in combination, however, worked synergistically through presynaptic and postsynaptic mechanisms to depress EPSCs to levels greater than $\mathrm{D}_{1 / 5}$ receptor activation alone. After chronic cocaine administration, the function of $\mathrm{DA}_{1 / 5}$ and CRF receptors switched from inhibitory to excitatory. In slices from cocaine-treated animals, putative BLA-mPFC EPSCs were depressed through a presynaptic mechanism. Now, activation of either $\mathrm{D}_{1 / 5}$ or $\mathrm{CRF}_{2}$ receptors increased the cocaine-induced, depressed EPSCs. Additionally, simultaneous activation of presynaptic $\mathrm{D}_{1 / 5}$ and $\mathrm{CRF}_{2}$ receptors led to further enhancement of EPSCs. These data indicate that CRF acting synergistically with DA normally potentiates $\mathrm{D}_{1 / 5}$-induced synaptic depression. However, after chronic cocaine, the combined synergistic actions of DA and CRF switched polarity to enhance facilitation of BLA-mPFC glutamatergic transmission. Also unmasked after acute withdrawal from chronic cocaine are endogenous, tonic-inhibitory $\mathrm{D}_{2}$-like and tonic-facilitatory $\mathrm{CRF}_{2}$ receptor actions. These multiple functional and receptor changes may underlie the altered, possibly aberrant, decision-making process after chronic cocaine.
\end{abstract}

Key words: addiction; CRF; dopamine; glutamate; SKF81297; NBI30775; Astressin ${ }_{2} \mathrm{~B}$; stress

\section{Introduction}

Cocaine addiction is a chronic medical disorder characterized by compulsive cocaine use despite adverse consequences (Leshner, 1996), and is associated with changes within prefrontal cortex (PFC) networks (Everitt and Robbins, 2005).

The amygdala is an important component of PFC networks by its involvement in decision-making processes as it encodes the emotional value/intensity of environmental stimuli and outcome-action associations (Winston et al., 2005; De Martino et al., 2006). Basolateral amygdala (BLA) neurons relay this infor-

Received Jan. 7, 2007; revised Dec. 5, 2007; accepted Dec. 5, 2007.

This work was supported by Grants DA011991, DA017727, MH066996, MH058327, and the Center for Addiction Research at the University of Texas Medical Branch. We appreciate constructive discussion and review by Drs. G. Swanson and M. Joëls.

Correspondence should be addressed to Dr. Joel P. Gallagher, Department of Pharmacology and Toxicology, The University of Texas Medical Branch, 301 University Boulevard, Galveston, TX 77555-1031. E-mail: jpgallag@utmb.edu.

L. Orozco-Cabal's present address: Facultad de Medicina, Universidad de Los Andes, Carrera 1, No. 18A-10, Edificio Q, Piso 8, Of. 816, 29232 Bogotá, D.C., Colombia.

DOI:10.1523/JNEUROSCI.2666-07.2008

Copyright $\odot 2008$ Society for Neuroscience $\quad$ 0270-6474/08/280529-14\$15.00/0 mation by excitatory efferents to pyramidal neurons in the medial PFC (mPFC) (Krettek and Price, 1977; Gabbott et al., 2006; Orozco-Cabal et al., 2006a). However, after chronic cocaine use, BLA-mPFC neurotransmission may become aberrant as cocaine-dependent individuals exhibit inappropriate utilization of emotional information to guide behavior (Schoenbaum et al., 2006).

Dopamine (DA) and corticotrophin-releasing factor (CRF) are essential contributors within the PFC (Koob, 1999; Kelley, 2004) during cocaine abuse. DA mediates incentive salience of reward-related stimuli (Berridge, 2007), and is a critical modulator of pyramidal neuron excitability and excitatory synaptic transmission in the PFC (Seamans and Yang, 2004; Floresco and Tse, 2007). Pyramidal neurons in the mPFC and their afferents express receptors for DA ( $\mathrm{D}_{1}$ - and $\mathrm{D}_{2}$-like) (Smiley et al., 1994; Krimer et al., 1997). After chronic cocaine administration, DA neurotransmission in the PFC undergoes significant changes (Williams and Steketee, 2005), time-dependent changes that may be caused by increases/decreases in binding to DA receptor subtypes (Ben-Shahar et al., 2007). In cocaine addicts, changes in DA 
actions have been associated with executive dysfunction (Dackis and Gold, 1985; Volkow et al., 1996).

CRF plays a crucial role in stress responses by integrating endocrine and neural systems to facilitate coping in mammals (Vale et al., 1981). CRF effects are mediated by two G-protein-coupled receptors, $\mathrm{CRF}_{1}$ and $\mathrm{CRF}_{2}$. Extrahypothalamic $\mathrm{CRF}$ receptors regulate cellular excitability and synaptic plasticity within frontolimbic circuits (Liu et al., 2004), and because CRF is released (Yan et al., 1998) within layer V of the PFC, activation of PFCCRF receptors may affect local neurotransmission.

Chronic cocaine administration is associated with CRF hypersecretion (Richter et al., 1995), whereas CRF receptor binding was increased or decreased (Goeders et al., 1990; Ambrosio et al., 1997). Chronic cocaine induced a switch from an expected $\mathrm{CRF}_{2}-$ mediated depression of glutamatergic transmission to one of facilitation (Liu et al., 2005).

The effects of chronic cocaine administration on BLA-mPFC EPSCs remain unclear. In controls, exogenously applied DA induced depression of EPSCs at putative BLA-mPFC synapses. Furthermore, this DA-induced EPSC depression was enhanced significantly when combining DA with CRF, whereas CRF itself had no action. After chronic cocaine administration in vivo, a switch in function of DA and CRF actions became apparent. Presynaptically, $\mathrm{D}_{1}$-like receptors facilitated EPSCs with emergence of a $\mathrm{D}_{2}$-like depressant tone. $\mathrm{CRF}$ again enhanced the action of DA, but now the combination facilitated rather than depressed EPSCs. In addition, CRF itself now enhanced EPSCs via an endogenous facilitatory $\mathrm{CRF}_{2}$ receptor tone.

These multiple changes in DA and CRF modulation of putative BLA-mPFC EPSCs after chronic cocaine may provide aberrant emotional information that contributes to compulsive drugseeking and drug-taking behaviors in cocaine-dependent subjects.

\section{Materials and Methods}

Subjects and treatment groups. After $5 \mathrm{~d}$ of acclimatization to the colony room, male rats [postnatal day 22 (P22)-P25, 75 g, Sprague Dawley, Harlan, Houston, TX] were divided into two groups. Control rats (saline-treated/control group) received $0.9 \%$ saline injections ( $1 \mathrm{ml} / \mathrm{kg}$, i.p.) in their home cages according to the same schedule as chronic cocainetreated (chronic cocaine-treated group; $15 \mathrm{mg} / \mathrm{kg}$, i.p., twice a day for $14 \mathrm{~d}$ at 9:00 A.M. and 4:00 P.M.) rats. The rats (P36-P39, 175-225 g) were decapitated within $17-24 \mathrm{~h}$ after receiving their last injection of saline or cocaine, and their brains were rapidly removed for brain slice preparation. Rats of this age group are considered adolescent to young adult and would be most comparable in age to the most prevalent age group experiencing drug abuse, because over one-half (51\%) of America's teenagers have tried an illicit drug by the time they finish high school (Rice, 1999).

Animal experiments were performed in accordance with the National Research Council Guide for the Care and Use of Laboratory Animals.

PFC slice. The brains were immersed in a modified cold $\left(\sim 4^{\circ} \mathrm{C}\right)$ artificial CSF (ACSF) bubbled continuously with $95 \% \mathrm{O}_{2} / 5 \% \mathrm{CO}_{2}$ to maintain proper $\mathrm{pH}$ (7.3-7.4). The composition of the ACSF solution was as follows (in mM): $117 \mathrm{NaCl}, 3.5 \mathrm{KCl}, 1.2 \mathrm{NaH}_{2} \mathrm{PO}_{4}, 2.5 \mathrm{CaCl}_{2}, 1.3 \mathrm{MgCl}_{2}$, $25 \mathrm{NaHCO}_{3}$, and 11.5 glucose. Subsequently, brains were cut at the level of the optic chiasm, and $400 \mu \mathrm{m}$ coronal slices containing the PFC [approximately $+3.20 \mathrm{~mm}$ from bregma (Paxinos and Watson, 1998)] were made from the remaining tissue block using a Vibroslice (World Precision Instruments, Sarasota, FL). After $1 \mathrm{~h}$ in ACSF at $33 \pm 2^{\circ} \mathrm{C}$ for recovery, individual slices were transferred and submerged in a cylindrical Plexiglas recording chamber (volume $=2 \mathrm{cc}$ ) and continuously perfused $(2.0-2.5 \mathrm{ml} / \mathrm{min})$ with ACSF maintained at $33 \pm 2^{\circ} \mathrm{C}$. The recording chamber was transilluminated to facilitate identification of $\mathrm{mPFC}$ cortical layers for electrode placement.

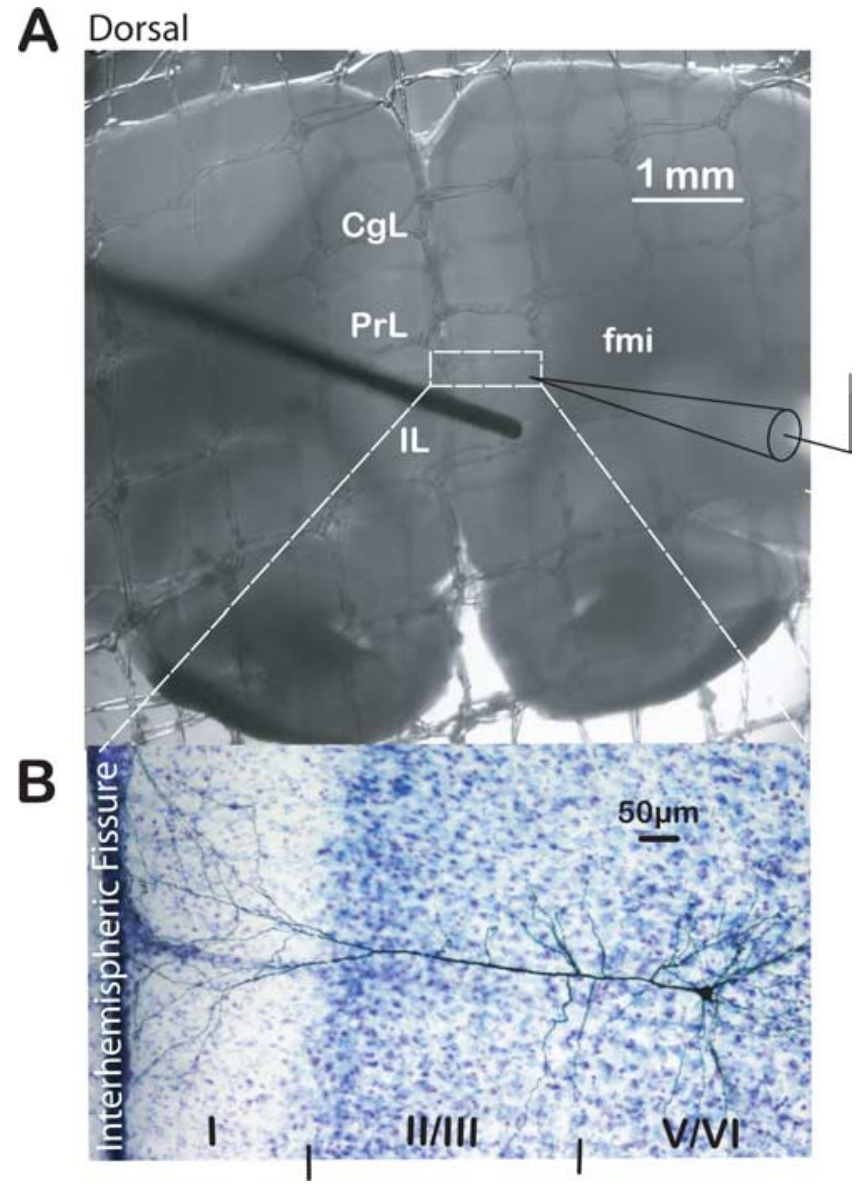

Figure 1. Brain slice preparation of the rat PFC used to study putative BLA-mPFC synapse. $A$, Photograph of a PFC slice submerged in our recording chamber depicting the position of stimulating (from the left) and recording (from the right) electrodes for EPSC recordings. CgL, Cingulate cortex; fmi, forceps minor. Scale bar, $1 \mathrm{~mm}$. Dashed rectangle depicts area expanded below of typical biocytin-filled, layer V, PrL pyramidal neuron from which recordings were made. $\boldsymbol{B}$, Photograph of DAB-stained layer V pyramidal neuron filled with biocytin in the cresyl violet-counterstained $\mathrm{mPFC}$. Cortical layers are indicated by roman numerals at the bottom of the photograph. Scale bar, $50 \mu \mathrm{m}$.

Stimulating and recording electrode placements were made within the slice obtained at $+3.20 \mathrm{~mm}$ from bregma. Briefly, the concentric stimulating electrode was positioned within layer $\mathrm{V}$ of the infralimbic cortex (IL) at $400-450 \mu \mathrm{m}$ lateral to the interhemispheric fissure (Fig. $1 \mathrm{~A}$ ). Positioning of the stimulating electrode is based on our previous quantitative analyses, which had determined that the highest labeling intensity, after injection of DiI into the BLA (Orozco-Cabal et al., 2006a), appeared along layer $\mathrm{V}$ in the infralimbic cortex. The recording electrode was then positioned within layer $\mathrm{V}$ of the prelimbic cortex (PrL) separated by $600-800 \mu \mathrm{m}$ dorsal to the stimulating electrode. The recording electrode was also $\sim 600-700 \mu \mathrm{m}$ lateral to the interhemispheric fissure; this position was aligned as a continuum from the recording site and represented the highest density of DiI labeling (see Fig. 2) (Orozco-Cabal et al., 2006a). After recording, biocytin labeling (Fig. $1 \mathrm{~B}$ ) of the recorded layer V-VI pyramidal neurons provided another monitor of these neurons within prelimbic layers V-VI. Positioning of the stimulating electrode within the slice was based on our previous published work (Orozco-Cabal et al., 2006a).

Whole-cell patch-clamp recordings. Whole-cell patch-clamp recordings were performed from mPFC-layer $\mathrm{V}$ pyramidal neurons using patch electrodes with tip resistances of 3-4 M $\Omega$ when filled with a solution consisting of the following (in mM): $122 \mathrm{~K}$-gluconate; $0.3 \mathrm{CaCl}_{2} ; 2 \mathrm{MgCl}_{2}$; 1 EGTA; 10 HEPES; $5 \mathrm{Na}_{2}$-ATP; $0.4 \quad \mathrm{Na}_{3}$-GTP; $5 \mathrm{~N}-(2,6-$ dimethylphenylcarbamoylmethyl) triethylammonium bromide (QX314), and $0.2 \%$ biocytin. The $\mathrm{pH}$ of the internal solution was ad- 
justed to 7.2 with $\mathrm{KOH}$, and osmolality was corrected to $280-290$ $\mathrm{mmol} / \mathrm{kg}$ with sucrose. In addition, a modified internal electrode solution containing $1 \mathrm{~mm}$ guanosine $5^{\prime}-O$ - $[\beta$-thio] diphosphate (GDP $\beta S$ ) was used to inactivate postsynaptic G-protein-coupled receptors (GPCRs). The effectiveness of GDP $\beta$ S at blocking postsynaptic GPCRs was assayed for the loss of a baclofen-induced (100 $\mu \mathrm{M}$, drop applied) outward current in mPFC-layer V pyramidal neurons.

Recorded pyramidal neurons were identified based on the membrane electrical properties (Yang et al., 1996; Orozco-Cabal et al., 2006a) and were included for analyses if they maintained stability with a resting membrane potential more negative than $-60 \mathrm{mV}$. Access resistance was monitored continuously throughout recordings; neurons were discarded if access resistance exceeded $30 \mathrm{M} \Omega$.

Evoked EPSCs. Putative excitatory afferents to the mPFC from the basolateral amygdala were stimulated at $0.05 \mathrm{~Hz}$ with a Grass S- 88 stimulator (with isolation units) through a low-resistance concentric electrode (Frederick Haer, Bowdoinham, ME) placed in cortical layer $\mathrm{V}$ (400-450 $\mu \mathrm{m}$ from the interhemispheric fissure of the slice) and within the IL cortex (Fig. 1 A) (Orozco-Cabal et al., 2006a). The recording electrode was situated within layer V of the PrL mPFC cortex $(\sim 700 \mu \mathrm{m}$ from the interhemispheric fissure) (Fig. $1 A$ ). Both stimulating and recording electrodes were positioned under visual control using a dissecting microscope $(0.5 \times$; Nikon Instruments, Melville, NY). We are aware that other glutamatergic afferents, arising from sources in addition to the BLA such as midline thalamic nuclei, the hippocampus, and septum, may course along our stimulation site. As a result, we have modified our description of the pathway we are stimulating and the synapse from which we are recording as the "putative" BLA-mPFC pathway and its synapse. Nonetheless, in support of our experimental results and description of the excitatory synapses from which we recorded as being putative BLA-mPFC synapses, Gabbott et al. (2006) concluded that excitatory BLA afferents to mPFC pyramidal neuron spines formed predominantly (>94\%) asymmetric (Gray type I) monosynaptic synapses.

EPSCs were recorded at $-70 \mathrm{mV}$ holding membrane potential and in the presence of (2S)-3-[[(1S)-1-(3,4-dichlorophenyl)ethyl]amino-2hydroxypropyl] (phenylmethyl)phosphinic acid (CGP55845; $2 \mu \mathrm{M}$ ) to block $\mathrm{GABA}_{\mathrm{B}}$ receptors and D-2-amino-5-phosphonovaleric acid (DAPV; $10 \mu \mathrm{M}$ ) to partially block NMDA receptors while preventing signal contamination by recurrent activity within the slice preparation. The membrane holding potential $(-70 \mathrm{mV})$ corresponds to the reversal potential for $\mathrm{Cl}^{-}$determined experimentally and is also based on the composition of the bath and pipette solutions; holding at this membrane potential controlled for $\mathrm{GABA}_{\mathrm{A}}$ receptor-mediated conductances (supplemental Fig. 1, available at www.jneurosci.org as supplemental material). EPSCs obtained under these recording conditions consisted primarily of non-NMDA-mediated postsynaptic responses (Orozco-Cabal et al., 2006a). This recording solution would have prevented activation of possible disynaptic inhibitory currents arising from excitatory activation of inhibitory interneurons within our slice preparation. Data were acquired using an Axoclamp-2A amplifier (Axon Instruments, Foster City, $\mathrm{CA}$ ) with a switching frequency of $5-6 \mathrm{kHz}$ (30\% duty cycle; gain of 3 $\mathrm{nA} / \mathrm{mV}$, time constant $=20 \mathrm{~ms}$ ). To test for drug effects, the stimulus intensity was set to elicit $50-70 \%$ of the maximal response. Current signals were low-pass filtered at $1 \mathrm{kHz}$ with a 4-pole Bessel filter (Warner Instrument, Hamden, CT), digitized at $5.5 \mathrm{~Hz}$ (DigiData 3200 interface, Axon Instruments), and stored on a Dell computer for off-line analysis using pClamp (version 9.2; Axon Instruments) software.

Evoked fast IPSCs. The stimulating electrode was placed in layer II-III of the PrL cortex adjacent to the recording electrode (100-200 $\mu \mathrm{m}$ interelectrode distance), which was located within layer $\mathrm{V}$ of the $\mathrm{mPFC}$ cortex ( $\sim 700 \mu \mathrm{m}$ from the interhemispheric fissure). Stimulating and recording electrodes were positioned under visual control using a dissecting microscope (0.5×; Nikon Instruments). Evoked fast IPSCs (fIPSCs) were acquired in the presence of CGP55845 (2 $\mu \mathrm{M}), 6,7-$ dinitroquinoxaline-2,3(1H,4H)-dione (DNQX; $20 \mu \mathrm{M})$, and D-APV (50 $\mu \mathrm{M})$, while the neuron was clamped at $-55 \mathrm{mV}$ membrane potential (supplemental Fig. 1, available at www.jneurosci.org as supplemental material). Pharmacological blockade of glutamate receptors did not have a depressant effect on f-IPSCs, suggesting that positioning of the stimu- lating electrode in layer II-III of the PrL cortex and in close proximity $(100-200 \mu \mathrm{m})$ to the recording electrode yielded direct monosynaptic orthodromic stimulation of inhibitory interneurons in the slice preparation. Additionally, f-IPSCs could be completely blocked using a mixture of picrotoxin (PTX; $50 \mu \mathrm{M}$ ) and bicuculline methiodide (BMI; $10 \mu \mathrm{M}$ ), which confirmed the monosynaptic generation of these currents and their mediation by $\mathrm{GABA}_{\mathrm{A}}$ receptors (supplemental Fig. 1, available at www.jneurosci.org as supplemental material). QX314 was not added to the internal pipette solution for f-IPSC recordings.

mEPSCs. Action potential-independent miniature EPSCs (mEPSCs) were collected for $2 \mathrm{~min}$ after a $20 \mathrm{~min}$ period after the addition of tetrodotoxin (TTX; $1 \mu \mathrm{M}$ ) to the standard ACSF and analyzed off-line using Synaptosoft Mini Analysis software (Synaptosoft, Fort Lee, NJ). mEPSC events were defined as amplitudes above a preset baseline/noise level (5 pA). D-APV (50 $\mu \mathrm{M})$, PTX $(50 \mu \mathrm{M})$, and BMI (10 $\mu \mathrm{M})$ were added to the perfusion solution during all mEPSC recordings. Holding membrane potential $=-70 \mathrm{mV}$.

Drug application. All drugs and drug combinations were dissolved in ACSF and superfused at known concentrations. A wash-in period of at least $12 \mathrm{~min}$ was allowed to establish equilibrium before drug effects were analyzed in all experiments. After reaching equilibrium concentrations, drug effects were analyzed over the next 15-20 min period. During washout, return of monitored parameters to predrug or drug combination baseline values was used as an indication of recovery and reversibility (usually 15-20 min).

The following drugs were used: rat/human corticotropin-releasing factor (r/hCRF), cyclo (31-34) [D-Phe11,His12,C(a)MeLeu13,39, Nle17,Glu31,Lys34] Ac-Svg(8-40) trifluoroacetate salt [Astressin ${ }_{2} \mathrm{~B}$ $\left(\right.$ Ast $\left._{2} \mathrm{~B}\right)$ ], D-APV, DNQX, BMI, PTX, dopamine hydrochloride (DA), $S(-)$-raclopride L-tartrate, SKF81297 (SKF), QX314, baclofen, TTX, EGTA, and GDP $\beta$ S from Sigma-Aldrich (St. Louis, MO); CGP55845 and ( $R$ )-(+)-7-chloro-8-hydroxy-3-methyl-1-phenyl-2,3,4,5-tetrahydro-

$1 \mathrm{H}$-3-benzazepine hydrochloride [SCH23390 (SCH)] from Tocris Cookson (Ellisville, MO); and 2,5-dimethyl-3-(6-dimethyl-4methylpyridin-3-yl)-7-dipropylaminopyrazolo[1,5-a] pyrimidine [NBI30775 (NBI)/R121919] courtesy of D. E. Grigoriadis (Neurocrine Biosciences, San Diego, CA).

Data analyses. To avoid cumulative effects of drugs, only one cell per slice was used for recording and data collection. The amplitudes of EPSCs and f-IPSCs were normalized to baseline responses and expressed as the mean percentage of baseline \pm SEM. To test for the effects of concentration-dependent effects of drugs applied individually ( $\mathrm{r} / \mathrm{hCRF}$, DA, SKF81297, NBI30775, Ast ${ }_{2}$ B, and raclopride), we performed ANOVAs for repeated measures with Bonferroni correction using concentration as a repeated factor. To assess the influence of $\mathrm{r} / \mathrm{hCRF}$ on the effects of SKF81297 or DA, we performed two-way mixed ANOVAs with Bonferroni correction using concentration as a repeated factor and treatment as between-subjects factor. To calculate $\mathrm{IC}_{50}$ and $\mathrm{EC}_{50}$ values for SKF81297, percentage change of EPSC amplitude after SKF81297 (10 $\mu \mathrm{M}$ ) application was set as the maximal data point. For analyses of pairedpulse facilitation data, mixed ANOVAs with interstimulus interval and concentration as repeated-within-subjects factor, treatment as betweensubjects factor, and post hoc tests were performed. The effects of chronic cocaine administration on $\mathrm{r} / \mathrm{hCRF}$ and SKF or DA were tested using mixed ANOVAs with cocaine/saline-treatment groups as betweensubjects factor and concentration as within-subjects factor with Bonferroni correction for multiple comparisons. Chronic cocaine effects on passive membrane electrical properties were analyzed using the WaldWolfowitz runs test. Significance level was defined as $p \leq 0.05, n$ indicates number of neurons, and data are presented as mean \pm SEM.

Importantly, because brain slices from cocaine-treated rats were collected after only $17-24 \mathrm{~h}$ of withdrawal from cocaine administration in all chronic cocaine administration and acute withdrawal experiments, it is possible that cocaine withdrawal per se may have an effect on BLAmPFC synaptic transmission and CRF and DA receptor-mediated modulation. However, our experimental design does not allow a clear distinction between the effects of chronic cocaine administration versus those of acute (17-24 h) cocaine withdrawal. Therefore, we are not making such 
a distinction and refer to our findings in this group of rats as chronic cocaine induced.

\section{Results}

\section{Experiments in}

saline-treated/control rats

$D_{1 / 5}$ receptor-mediated depression of excitatory transmission is enhanced on activating $C R F_{1}$ receptors at $m P F C-B L A$ synapse

We initiated our investigation of DA actions at the putative BLA-mPFC synapse with the selective $D_{1 / 5}$ agonist SKF81297. Previous studies had confirmed that $\mathrm{D}_{1}$ like receptors are the most prevalent type of dopamine receptors within layer $\mathrm{V}$ of the mPFC. In addition, because DA and CRF systems are implicated in stress and cocaine abuse, we investigated a possible interaction between these two systems by examining the combined actions of SKF81297 and r/hCRF, a CRF agonist active at both $\mathrm{CRF}_{1}$ and $\mathrm{CRF}_{2}$ receptors.

SKF81297 depressed putative BLA$\mathrm{mPFC}$ excitatory synaptic transmission in a concentration-dependent manner (Fig. $2 A)\left(\mathrm{IC}_{50}=0.6 \mu \mathrm{M}\right)$. SKF $[1 \mu \mathrm{M}(82.4 \pm$ $1.3 \% ; p<0.05)$ and $10 \mu \mathrm{M}(74.8 \pm 1.6 \%$; $p<0.05)$ ] significantly depressed EPSCs $\left(F_{(4,60)}=59.5 ; p<0.01\right)$. Lower concentrations of SKF did not affect EPSCs (SKF at $10 \mathrm{nM}, 96.7 \pm 0.7 \% ; p>0.05$; SKF at 100 $\mathrm{nM}, 97.0 \pm 2.3 \% ; p>0.05)$. Consistent with a $\mathrm{D}_{1 / 5}$ receptor-mediated effect, the effects of SKF81297 (1 and $10 \mu \mathrm{M}$ ) on EPSCs were blocked by SCH23390 (10 $\mu \mathrm{M})$

(Fig. $2 B$ ), a selective $\mathrm{D}_{1 / 5}$-antagonist. $\mathrm{SCH}(10 \mu \mathrm{M})$ prevented SKF-induced depression of EPSCs [SKF $(1 \mu \mathrm{M})$ plus SCH, $101.4 \pm 3.4 \%$; SKF $(10 \mu \mathrm{M})$ plus SCH, $101.2 \pm 3.3 \% ; p>0.05$ compared with baseline; $p<0.05$ compared with $\operatorname{SKF}(1,10 \mu \mathrm{M})$ alone]. In addition, SCH23390 did not affect membrane conductance or evoked EPSC amplitude from pyramidal neurons in our $\mathrm{mPFC}$ slice preparation.

Unlike SKF81297, r/hCRF (12.5-100 nM) did not affect putative BLA-to-mPFC EPSCs (Fig. 2C) (R/hCRF at $12.5 \mathrm{~nm}, 96.0 \pm$ $1.6 \%$; at $50 \mathrm{nM}, 99 \pm 1.3 \%$; and at $100 \mathrm{nM}, 95.8 \pm 1.4 \% ; F_{(3,21)}=$ $1.52 ; p>0.05)$. There was also no apparent $\mathrm{CRF}_{1}-$ or $\mathrm{CRF}_{2}$ dependent endogenous tone after application of selective CRF receptor antagonists, NBI30775 (Heinrichs et al., 2002) and Astressin 2 B (Rivier et al., 2002), respectively (Fig. 2C). We observed no changes of EPSCs $(95.9 \pm 1.3 \%)$ after 20 min of continuous application of NBI30775 $(500 \mathrm{nM})$ or after washout $\left(98.7 \pm 2.2 \% ; F_{(2,8)}=1.89 ; p>0.05\right)$. Similarly, Ast $_{2} \mathrm{~B}$ did not affect EPSCs (103.9 $\pm 1.8 \%)$ after $20 \mathrm{~min}$ of continuous application or after washout $\left(98.7 \pm 2.7 \% ; F_{(2,8)}=1.89 ; p>0.05\right)$. Together, these results demonstrated that neither exogenous r/hCRF ( $\leq 100 \mathrm{~nm}$ ) or endogenous CRF modulates BLA-mPFC EPSCs in saline-treated control rats. The lack of exogenous and endogenous actions of CRF on evoked EPSCs at this synapse differed from CRF actions at the BLA-central amygdala nucleus synapse, where exogenously applied $\mathrm{r} / \mathrm{hCRF}\left(\mathrm{IC}_{50}=0.32 \mathrm{nM}\right.$ ) depressed evoked EPSCs by a postsynaptic $\mathrm{CRF}_{1}$-mediated ac-
SALINE/CONTROL

B
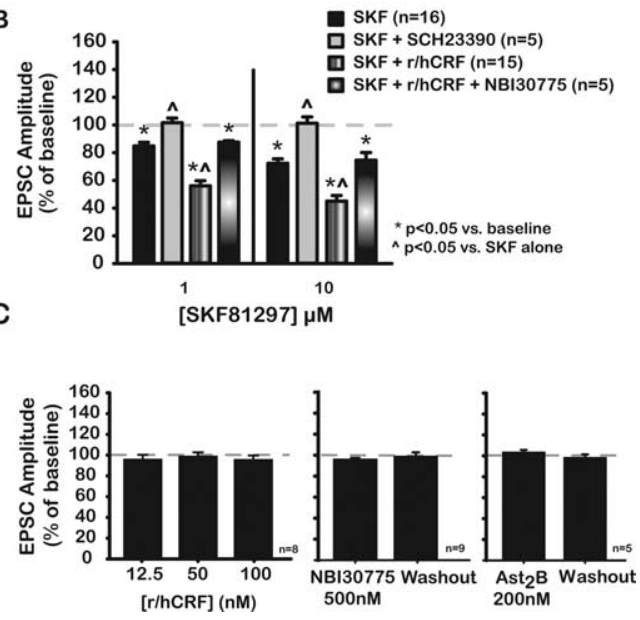

Figure 2. Depression of excitatory transmission at putative BLA-mPFC synapse mediated by the $D_{1}$-like $\left(D_{1 / 5}\right)$ agonist $S K F$ is enhanced through activation of $\mathrm{CRF}_{1}$ receptors in saline-treated control rats, whereas neither $\mathrm{r} / \mathrm{hCRF}$ itself nor CRF antagonists op traces) and SKF plus $50 \mathrm{~nm} \mathrm{r/hCRF} \mathrm{(bottom} \mathrm{traces).} \mathrm{Concentration-response} \mathrm{curves} \mathrm{for} \mathrm{each} \mathrm{treatment} \mathrm{group} \mathrm{are} \mathrm{shown}$ ther depressed EPSCs, indicating that $\mathrm{r} / \mathrm{hCRF}(50 \mathrm{~nm})$ facilitated SKF effects at this putative BLA-mPFC synapse. $\boldsymbol{B}$, Bar graph 作 There no significant differences ( $p>0.05)$ between EPSC values after SKF $(1,10 \mu \mathrm{M})$ compared with SKF $(1,10 \mu \mathrm{M})$ plus Bar graphs summarizing lack of effects of different $\mathrm{r} / \mathrm{hCRF}$ concentrations on EPSCs. Neither NBI ( $500 \mathrm{~nm}$; center) nor Ast $\mathrm{B}$ ( $200 \mathrm{~nm}$; right) had any significant effects on EPSCs before or after washout.

tion, and antagonists revealed tonic activation of $\mathrm{CRF}_{1}$ and $\mathrm{CRF}_{2}$ receptors (Liu et al., 2004).

Surprisingly, the combination of r/hCRF ( $50 \mathrm{nM}$; a concentration not affecting EPSCs) with SKF81297 (1 or $10 \mu \mathrm{M})$ synergistically depressed EPSCs (Fig. $2 A, B$ ), i.e., to a greater extent than SKF81297 alone. In these experiments, we compared changes in EPSCs induced by increasing concentrations of SKF81297 (10 nM to $10 \mu \mathrm{M})$ to those caused by the combination of SKF81297 (10 nM to $10 \mu \mathrm{M}$ ) with $\mathrm{r} / \mathrm{hCRF}(50 \mathrm{~nm}$ ). As shown in Figure $2 A$, r/hCRF shifted the concentration-response curve for SKF81297 downward and to the left $\left(\mathrm{IC}_{50}=72 \mathrm{nM}\right.$ with $\mathrm{r} / \mathrm{hCRF}$ vs $600 \mathrm{nM}$ without $\mathrm{r} / \mathrm{hCRF}$; 44.9\% EPSC reduction after $10 \mu \mathrm{M}$ SKF81297 compared with $55.1 \%$ reduction after the combination $[\mathrm{r} / \mathrm{hCRF}$ (50 nM) plus SKF81297 (10 $\mu \mathrm{M})]$ ), suggesting that r/hCRF (50 $\mathrm{nM}$ ) acted to enhance $\mathrm{D}_{1 / 5}$ receptor-mediated depression of putative BLA-mPFC EPSCs in saline-treated control animals. In addition, the synergistic effects of r/hCRF (50 nM) on SKF81297mediated effects could be blocked completely by NBI30775 (500 $\mathrm{nM}$ ) (Fig. $2 B$ ), indicating that $\mathrm{r} / \mathrm{hCRF}$ effects were mediated primarily by $\mathrm{CRF}_{1}$ receptors in saline-treated control animals.

$r / h C R F_{1}$ facilitation of $D_{1 / 5}$-mediated depression of putative BLA$m P F C$ EPSCs was independent of $G A B A_{A}$-mediated

neurotransmission

Because CRF is known to colocalize with GABA in GABA terminals of PFC interneurons (Merchenthaler, 1984; Morin et al., 1999; Dautzenberg and Hauger, 2002; Gabbott et al., 2006), we tested whether the $\mathrm{CRF}_{1}$-induced enhancement of $\mathrm{D}_{1 / 5}$-mediated depression of EPSCs was related to r/hCRF-induced changes of 
$\mathrm{GABA}_{\mathrm{A}}$ neurotransmission. R/hCRF (50 nM) did not cause observable changes $(100.9 \pm 1.0 \%$ after $50 \mathrm{~nm}$ r/hCRF; $99.2 \pm 1.6 \%$ after washout; $\mathrm{r} / \mathrm{hCRF}$ effect, $\left.F_{(2,14)}=1.06 ; p>0.05 ; n=8\right)$ of fast $\mathrm{GABA}_{\mathrm{A}}$-mediated IPSCs (f-IPSCs) recorded from mPFClayer $\mathrm{V}$ pyramidal neurons (supplemental Fig. $1 A$, available at www.jneurosci.org as supplemental material), suggesting that enhancement of $\mathrm{GABA}_{\mathrm{A}}$ neurotransmission could not account for $\mathrm{r} / \mathrm{hCRF}$ facilitation of $\mathrm{D}_{1 / 5}$ receptor-mediated EPSC depression. However, an effect of $\mathrm{r} / \mathrm{hCRF}$ on $\mathrm{GABA}_{\mathrm{B}}$ neurotransmission could not be discounted, because all EPSC and f-IPSC recordings were performed in the presence of $2 \mu \mathrm{M}$ CGP55845, a selective $\mathrm{GABA}_{\mathrm{B}}$ receptor antagonist that blocks both presynaptic and postsynaptic $\mathrm{GABA}_{\mathrm{B}}$ receptors.

$R / h C R F$ enhanced the depressant effect of DA on putative BLA$m P F C$ EPSCs in the presence of a $D_{2 / 3}$ receptor antagonist

Because SKF81297 is not the endogenous ligand for $D_{1 / 5}$ receptors, we tested the effects of DA $(10 \mu \mathrm{M})$ in the presence of raclopride $(10 \mu \mathrm{M})$, a selective $\mathrm{D}_{2 / 3}$ receptor antagonist, alone and in combination with $\mathrm{r} / \mathrm{hCRF}$ (Fig. 3 ). Blocking $\mathrm{D}_{2 / 3}$ receptors was necessary because previous studies demonstrated that $\mathrm{D}_{2 / 3}$ receptor activation decreases non-NMDA EPSCs (Cepeda et al., 1992; Hsu et al., 1995). Raclopride $(10 \mu \mathrm{M})$ did not cause significant changes in the amplitude of EPSCs $(98.9 \pm 3.9 \%$ of baseline; paired $t=0.27 ; p>0.05 ; n=5)$, suggesting that $\mathrm{D}_{2 / 3}$ receptors are not tonically activated by endogenous DA in slices from saline-treated animals [but see raclopride effects after chronic cocaine (Fig. 7A)].

As shown in Figure 3, $A$ and $B$, DA $(10 \mu \mathrm{M})$ reversibly depressed EPSCs in the presence of raclopride (10 $\mu \mathrm{M} \mathrm{DA}, 76.6 \pm$ $1.5 \%$; $p<0.01$; after washout, $97.7 \pm 1.3 \%$; $p>0.05$; DA effect, $\left.F_{(2,18)}=118.83 ; p<0.01\right)$. Combining $\mathrm{r} / \mathrm{hCRF}(50 \mathrm{~nm})$ with DA resulted in an enhancement of DA effects on EPSCs [23.4\% reduction after $10 \mu \mathrm{M}$ DA compared with $40.7 \%$ reduction after the combination $10 \mu \mathrm{M}$ DA plus $50 \mathrm{nM} \mathrm{r} / \mathrm{hCRF}\left(\mathrm{r} / \mathrm{hCRF} \times \mathrm{DA}, F_{(2,24)}\right.$ $=19.07 ; p<0.01 ; \mathrm{r} / \mathrm{hCRF}$ effect, $F_{(1,18)}=53.93 ; p<0.01 ; \mathrm{DA}$ effect, $\left.\left.F_{(2,24)}=281.75 ; p<0.01\right)\right]$. Because DA effects were tested in the presence of raclopride, our results confirmed that dopamine inhibitory effects were mediated through $D_{1 / 5}$ receptors.

Postsynaptic $C R F_{1}$ receptors mediated $r / h C R F$ facilitation of presynaptic $D_{1 / 5}$ receptor-induced depression of putative BLAmPFC EPSCs

To determine the synaptic location (presynaptic vs postsynaptic) of $\mathrm{D}_{1 / 5}$ and $\mathrm{CRF}_{1}$ receptors, voltage-clamped pyramidal neurons were loaded with GDP $\beta S(1 \mathrm{~mm})$ dissolved in the patch electrode solution. GDP $\beta S$ is a nonhydrolyzable GDP analog that locks GPCRs in their inactive state (Andrade et al., 1986). Because $\mathrm{CRF}_{1}$ and $\mathrm{D}_{1 / 5}$ receptors are both GPCRs (Missale et al., 1998; Grammatopoulos et al., 2001), these receptors would be inactivated by GDP $\beta S$ if present postsynaptically. Consequently, putative presynaptic $\mathrm{CRF}_{1^{-}}$and $\mathrm{D}_{1 / 5}$-mediated effects on EPSCs would remain unaltered by GDP $\beta$ S loaded into the recorded neuron; GDP $\beta S$ is not membrane permeable.

We assayed the effectiveness of GDP $\beta$ S at blocking postsynaptic GPCRs by testing for the loss of an outward (hyperpolarizing) current elicited by $\mathrm{GABA}_{\mathrm{B}}$ receptor activation (Andrade et al., 1986; Yamada et al., 1999) with baclofen (100 $\mu \mathrm{M})$. As shown in Figure $4 A$, GDP $\beta S$ blocked effectively a $\mathrm{GABA}_{\mathrm{B}}$-mediated outward current $\sim 20 \mathrm{~min}$ after whole-cell configuration was achieved. As a result, a 20 min waiting period was allowed before beginning to test for SKF81297 and r/hCRF effects in the presence of postsynaptic GDP $\beta$ S.

GDP $\beta S$, injected intracellularly into the recorded mPFC neu-
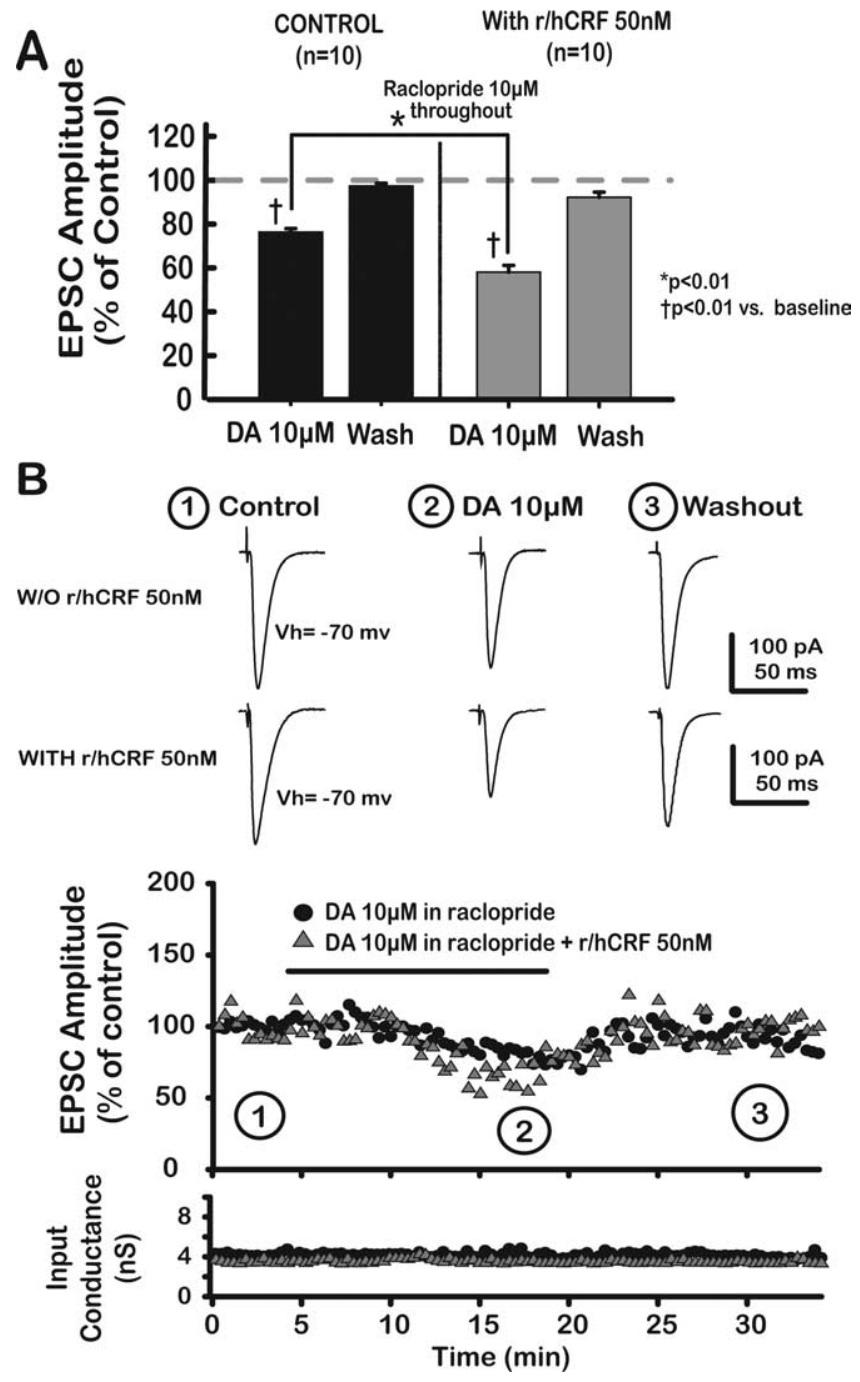

Figure 3. R/hCRF facilitated a DA-induced depression of putative BLA-mPFC EPSCs in the presence of raclopride, a $D_{2}$-like antagonist, in saline-treated animals. $A$, Bar graph depicts reversible and significant DA-mediated depression of EPSCs in the presence of $10 \mu \mathrm{m}$ raclopride. Raclopride, itself, did not have a significant effect on EPSC amplitude. DA (10 $\mu \mathrm{M})$ combined with $\mathrm{r} / \mathrm{hCRF}$ (50 nM) produced a greater depressive effect on EPSCs, indicating that $\mathrm{r} / \mathrm{hCRF}$ (50 nм) facilitated DA-induced EPSC depression. $\boldsymbol{B}$, Top, Representative averaged traces of EPSCs taken at different time points, indicated by numbers. Bottom, Input conductance plotted as a function of time.

ron, reduced the postsynaptic-GPCR-mediated actions of $\mathrm{D}_{1 / 5}$ and $\mathrm{CRF}_{1}$, which resulted in a reduced depression of EPSCs by DA and CRF ligands. Significantly, the actions of both concentrations of SKF81297 ( 1 or $10 \mu \mathrm{M})$ on EPSCs were diminished but not blocked by the presence of GDP $\beta$ S (Fig. $4 C$ ). GDP $\beta$ S reduced the depression by SKF at $1 \mu \mathrm{M}(93.5 \pm 1.4 \%$ vs $82.4 \pm 1.3 \%$ without GDP $\beta$ S; $p<0.01)$ and at $10 \mu \mathrm{M}(87.1 \pm 2.6 \%$ vs $74.9 \pm$ $1.6 \% ; p<0.01)$. These results support presynaptic and postsynaptic locations for $\mathrm{D}_{1 / 5}$ receptors activated by SKF81297, and the presynaptic actions are consistent with previous reports of $\mathrm{mPFC}$ presynaptic $D_{1 / 5}$ receptors on glutamatergic terminals in the mPFC, which when activated reduce the probability of glutamate release (Momiyama et al., 1996; Gao et al., 2001; Seamans et al., 2001a,b; Paspalas and Goldman-Rakic, 2004, 2005). Importantly, previous reports also indicated that activation of postsynaptic $\mathrm{D}_{1 / 5}$ receptors in layer $\mathrm{V}$ pyramidal neurons of the $\mathrm{mPFC}$ by $\mathrm{DA}$ receptor ligands at low micromolar concentrations enhanced 
A

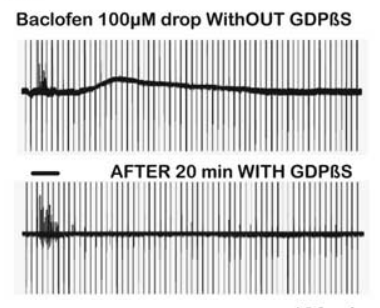

B

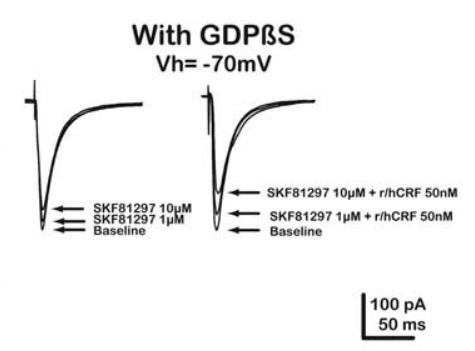

C
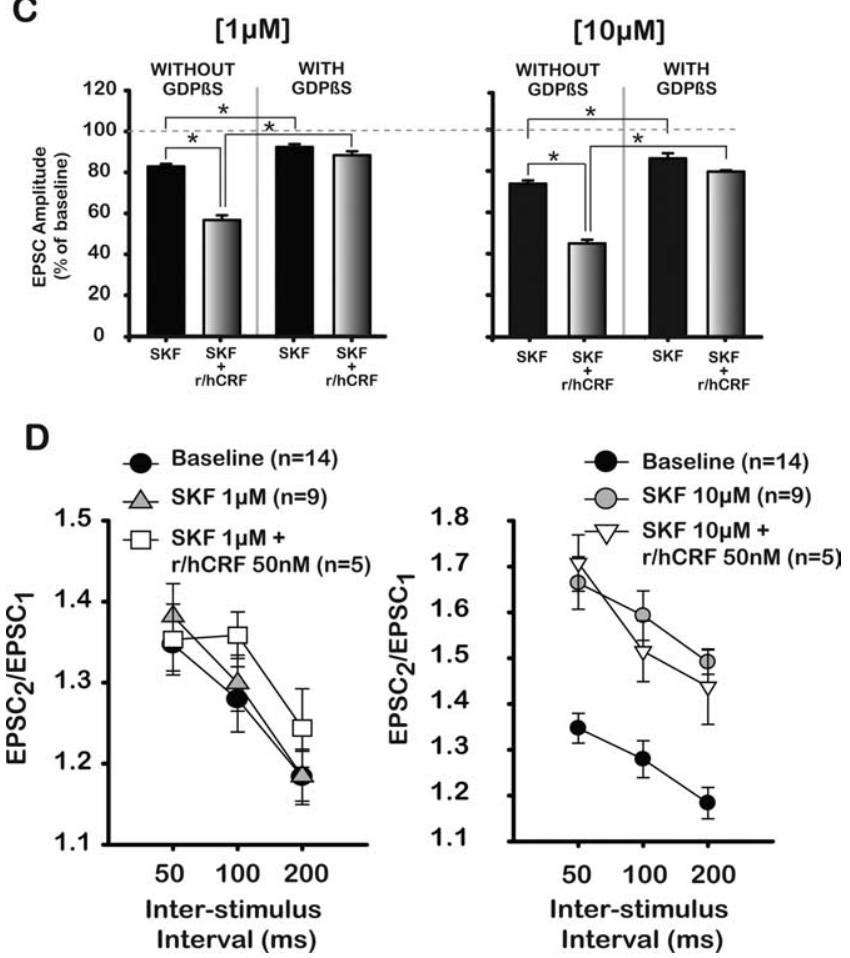

Figure 4. Postsynaptic $C R F_{1}$ receptors enhanced presynaptic $D_{1 / 5}$-mediated EPSC depression at the putative BLA-mPFC synapse in saline-treated control rats. $A$, Effects of GDP $\beta S$ on $\mathrm{GABA}_{\mathrm{B}}$ receptor-mediated outward current. Current traces obtained under voltage clamp $(-70$ $\mathrm{mV}$ ) from $\mathrm{mPFC}$-layer V pyramidal neurons under control conditions and with GDP $\beta S$ (1 mM) inside the recording electrode. Baclofen, $\mathrm{GABA}_{\mathrm{B}}$ receptor agonist, was drop applied (horizontal bar between top and bottom traces) into the bath while changes in membrane conductance were monitored. Top trace shows slow outward, hyperpolarizing current in response to baclofen application. Loading pyramidal neurons with GDP $\beta S(1 \mathrm{~mm}, \sim 20 \mathrm{~min})$ blocked GABA receptor-mediated current (bottom trace). Stimulus artifacts have been partially cut. $\boldsymbol{B}$, Representative traces of EPSC s from $\mathrm{mPFC}$-layer $V$ pyramidal neurons pyramidal neurons loaded with GDP $\beta$ S at baseline and after two different concentrations of SKF alone (left) or with coapplication of $r / h C R F$ (left). C, Bar graph depicts changes in EPSCs after SKF alone $(1,10 \mu \mathrm{m})$ or in combination with $\mathrm{r} / \mathrm{hCRF}(50 \mathrm{~nm})$ in the absence or presence of GDP $\beta S$. GDP $\beta S$ blocked the effects of SKF at $1 \mu \mathrm{M}$, but did not block SKF at $10 \mu \mathrm{m}$. In addition, GDP $\beta$ S blocked r/hCRF (50 nM)-induced facilitation of SKF ( $1 \mu \mathrm{m} ; 87.8 \pm 2.0 \%$ vs $44.8 \%)$ and $10 \mu \mathrm{M}(80.3 \pm 0.7 \%$ vs $51.9 \%$ ) effects on EPSCS. All treatments were significantly different from baseline. $\boldsymbol{D}$, Pairedpulse ratios (PPR $=$ EPSC $_{2} /$ EPSC $_{1}$ ) plotted as a function of interstimulus interval. SKF $(1 \mu \mathrm{m})$ did not change PPR values, but PPR values were significantly increased at all interstimulus intervals after $10 \mu \mathrm{m}$ SKF. The combination SKF (1 $\mu \mathrm{m})$ plus r/hCRF (50 nm) did not change PPR values from SKF alone or from baseline, whereas the combination SKF (10 $\mu \mathrm{m})$ plus r/hCRF (50 nм) significantly increased PPR values at all interstimulus intervals compared with baseline; there were no differences ( $p>0.05$ ) between PPR values after $10 \mu \mathrm{m}$ SKF in the presence or absence of CRF. ${ }^{*} p<0.05$ versus baseline.

NMDA-mediated excitatory responses, while having no or a small effect on non-NMDA EPSCs (Zheng et al., 1999; Zhou and Hablitz, 1999; Seamans et al., 2001a,b; Chen et al., 2004).

We also observed that GDP $\beta$ S blocked r/hCRF (50 nM)- induced enhancement of the depression by SKF $1 \mu \mathrm{M}(74.9 \pm$ $1.6 \%$ vs $87.1 \pm 2.6 \%)$ and $10 \mu \mathrm{M}(45.0 \pm 1.8 \%$ vs $80.3 \pm 0.7 \%)$ effects on EPSCs. All treatments were significantly different from baseline. These data suggest that $\mathrm{CRF}_{1}$ receptors are located postsynaptically only (see Fig. 9, left) and add support for a $D_{1 / 5}$ and $\mathrm{CRF}_{1}$ functional interaction postsynaptically. This result also confirms the effectiveness of the GDP $\beta$ S postsynaptically.

We further performed paired-pulse experiments $(50,100$, and $200 \mathrm{~ms}$ interstimulus intervals) (Fig. 4D) to corroborate the findings with GDP $\beta$ S. Paired-pulse ratios $\left(\mathrm{PPR}=\mathrm{EPSC}_{2} / \mathrm{EPSC}_{1}\right)$ were not significantly altered by SKF81297 ( $1 \mu \mathrm{M})$, a concentration that significantly reduced EPSCs, and suggested a postsynaptic location for $D_{1 / 5}$ receptors $(1.38 \pm 0.04$ at $50 \mathrm{~ms} ; p>0.05$; $1.30 \pm 0.03$ at $100 \mathrm{~ms} ; p>0.05 ; 1.18 \pm 0.03$ at $200 \mathrm{~ms} ; p>0.05)$. In contrast, $\mathrm{PPR}$ values were increased significantly after SKF81297 $(10 \mu \mathrm{M})$ at all interstimulus intervals $(1.36 \pm 0.02$ to $1.66 \pm 0.3$ at $50 \mathrm{~ms} ; p<0.05 ; 1.28 \pm 0.02$ to $1.59 \pm 0.02$ at 100 $\mathrm{ms} ; p<0.05 ; 1.18 \pm 0.2$ to $1.49 \pm 0.14 ; p<0.05)$, suggesting a presynaptic decrease in transmitter release probability. These data suggest the presence of both presynaptic and postsynaptic $\mathrm{D}_{1 / 5}$ receptors at the putative BLA-mPFC synapse and validate results with GDP $\beta S$. Furthermore, coapplication of r/hCRF (50 $\mathrm{nM})$ with SKF81297 $(1,10 \mu \mathrm{M})$ did not have a significant effect $(p>0.05)$ on PPR obtained with SKF alone (Fig. $4 D$ ), further corroborating GDP $\beta S$ data, and supporting a postsynaptic location for $\mathrm{CRF}_{1}$ receptors.

Collectively, these results also indicate that activation of postsynaptic $\mathrm{CRF}_{1}$ receptors enhanced EPSC depression mediated by presynaptic and postsynaptic $D_{1 / 5}$ receptors at the putative BLA-mPFC synapse in saline-treated control rats.

\section{Experiments in chronic cocaine-treated rats}

Chronic cocaine administration modified the passive membrane electrical properties of $m P F C$-layer $V$ pyramidal neurons Common membrane properties of $220 \mathrm{mPFC}-$ layer $\mathrm{V}$ pyramidal neurons recorded from slices of 111 saline/control and 109 cocaine-treated rats are shown in Table 1. Compared with mPFC-layer V pyramidal neurons from saline-treated control rats, neurons recorded from chronic cocaine-treated rats exhibited more depolarized resting membrane potentials $(p<0.01)$, higher membrane resistances $\left(R_{\mathrm{m}} ; p<0.05\right)$, and slower membrane time constants $(\tau ; p<0.01)$. Mixed ANOVAs yielded no significant differences $\left(F_{(1,38)}=0.96 ; p>0.05 ; n=40\right)$ in the current-voltage relationship between groups (data not shown).

\section{Evoked putative BLA-MPFC EPSCs were depressed and} spontaneous mEPSC frequency but not amplitude was reduced in chronic cocaine-treated rats

We examined possible changes in EPSCs from brains of chronic cocaine-treated rats compared with saline-treated controls. The input-output relationship that measured the amplitude of EPSCs as a function of stimulus intensity was shifted downward and to the right in slices from chronic cocaine-treated rats (Fig. $5 A$ ), indicating that EPSCs were significantly depressed (from a maximum value at $12 \mathrm{~V}$ stimulus of $254 \pm 17.0 \mathrm{pA}$ in saline-treated/ controls to $157 \pm 11.1 \mathrm{pA}$ in chronic cocaine-treated rats, a $55 \%$ reduction). EPSCs were reduced significantly (treatment $\times$ stimulus intensity, $F_{(4,40)}=11.2 ; p<0.01$; chronic cocaine effect, $F_{(1,8)}=41.0 ; p<0.01$; stimulus intensity effect, $F_{(5,40)}=172.5$; $p<0.01 ; n=10)$ in chronic cocaine-treated rats $(-7.8 \pm 1.0 \mathrm{pA}$ at $2 \mathrm{~V} ;-26.2 \pm 10.2 \mathrm{pA}$ at $4 \mathrm{~V} ;-85.2 \pm 14 \mathrm{pA}$ at $6 \mathrm{~V} ;-100.4 \pm$ $11.7 \mathrm{pA}$ at $8 \mathrm{~V} ;-134.2 \pm 7.2 \mathrm{pA}$ at $10 \mathrm{~V} ;-157.4 \pm 11.1 \mathrm{pA}$ at 12 $\mathrm{V})$ compared with saline-treated rats $(-7.3 \pm 3.6 \mathrm{pA}$ at $2 \mathrm{~V}$; 
Table 1. Comparison of membrane electrical properties of layer $V$ pyramidal neurons of the PL cortex recorded intracellularly from chronic cocaine- and saline-treated/control rats

\begin{tabular}{|c|c|c|c|c|c|}
\hline & \multicolumn{2}{|c|}{ Saline/control group } & \multicolumn{3}{|c|}{ Cocaine-treated group } \\
\hline & Mean & SEM & Mean & SEM & $p^{a}$ \\
\hline \multicolumn{6}{|l|}{ RMP } \\
\hline$(\mathrm{mV})$ & -65.9 & 0.3 & -62.3 & 1.2 & $<0.01$ \\
\hline$R_{\mathrm{m}}(\mathrm{M} \Omega)$ & 80.3 & 2.8 & 87.0 & 3.3 & $<0.05$ \\
\hline$\tau(\mathrm{ms})$ & 6.7 & 0.2 & 7.4 & 0.2 & $<0.01$ \\
\hline$n$ & 111 & & 109 & & \\
\hline
\end{tabular}

RMP, Resting membrane potential; $R_{\mathrm{m}^{\prime}}$ membrane resistance; $\tau$, membrane time constant. ${ }^{a}$ Wald-Wolfowltz test.

$-48.2 \pm 5.5 \mathrm{pA}$ at $4 \mathrm{~V} ;-125.8 \pm 6.1 \mathrm{pA}$ at $6 \mathrm{~V} ;-184.2 \pm 9.1 \mathrm{pA}$ at $8 \mathrm{~V} ;-220.7 \pm 9.0 \mathrm{pA}$ at $10 \mathrm{~V} ;-253.7 \pm 17.0 \mathrm{pA}$ at $12 \mathrm{~V})$.

Additionally, PPR values in slices from chronic cocainetreated rats were increased significantly compared with saline/ controls (Fig. 5B), suggesting a decrease in glutamate release at the putative BLA-mPFC synapse after chronic cocaine administration. Paired-pulse ratios $\left(\mathrm{PPR}=\mathrm{EPSC}_{2} / \mathrm{EPSC}_{1}\right)$ were plotted as a function of interstimulus interval (Fig. $5 B$, right). PPR values were significantly increased (treatment $\times$ time interval, $F_{(2,42)}=$ $17.0 ; p<0.01$; chronic cocaine effect, $F_{(1,25)}=11.6 ; p<0.01$; time interval effect, $\left.F_{(2,42)}=92.9 ; p<0.05 ; n=27\right)$ in slices from chronic cocaine-treated rats compared with saline-treated rats $(1.3 \pm 0.03$ vs $1.6 \pm 0.02$ at $50 \mathrm{~ms} ; p<0.01 ; 1.2 \pm 0.03$ vs $1.3 \pm$ 0.03 at $100 \mathrm{~ms} ; p=0.06 ; 1.1 \pm 0.03$ vs $1.1 \pm 0.05$ at $200 \mathrm{~ms} ; p>$ $0.05)$.

We also measured mEPSCs from mPFC-layer V pyramidal neurons in slices from chronic cocaine-treated rats and salinetreated rats in the presence of TTX $(1 \mu \mathrm{M})$. Consistent with a decrease in evoked glutamate release, analyses of mEPSCs revealed a significant reduction of mEPSC frequency with no change in mEPSC amplitude in chronic cocaine-treated rats compared with saline-treated rats (Fig. 5C,D). After chronic cocaine, mEPSP analyses showed a significant reduction in frequency, but not amplitude (mEPSC amplitude $=15.9 \pm 1.2 \mathrm{pA}$ for saline-treated/controls; $14.8 \pm 1.1 \mathrm{pA}$ for cocaine-treated rats, $t=0.67 ; p>0.05 ; n=10$; mEPSC interevent interval $=$ $3571 \pm 545 \mathrm{~ms}$ for saline-treated/controls; $6706 \pm 576 \mathrm{~ms}$ for cocaine-treated rats; $t=-3.94 ; p<0.01 ; n=10$ ).

In summary, the decrease in PPR values and mEPSC analyses suggested a reduction of glutamate release probability at the putative BLA-mPFC synapse in chronic cocaine-treated rats compared with saline-treated rats.

Activation of $D_{1 / 5}$ or $C R F_{2}$ receptors increased putative $B L A-m P F C$ EPSCs in chronic cocaine-treated rats

Subsequently, the $\mathrm{D}_{1 / 5}$ receptor-mediated modulation of EPSCs was analyzed in chronic cocaine-treated rats. As shown in Figure 6 A, SKF81297 $(10 \mu \mathrm{M})$ significantly increased EPSCs (114.1 \pm $2.5 \%)\left(F_{(4,40)}=15.3 ; p<0.01\right)$. Lower concentrations of SKF $(10$ $\mathrm{nM}, 100 \mathrm{nM}$, or $1 \mu \mathrm{M}$ ) did not affect EPSCs in chronic cocainetreated rats, effects not significantly different from those observed in saline-treated/control rats $(10 \mathrm{nM}, 99.1 \pm 1.3 \% ; p>$ $0.05 ; 100 \mathrm{nM}, 99.4 \pm 1.7 \% ; p>0.05 ; 1 \mu \mathrm{M}, 102.7 \pm 2.3 \% ; p>$ $0.05)$. This facilitatory effect was directly opposite to that observed in saline-treated/control animals, in which SKF81297 (10 $\mu \mathrm{M}$ ) depressed EPSCs (compare Fig. 2) ( $p<0.01$ ). SKF81297 (1 $\mu \mathrm{M})$ did not increase EPSCs significantly in chronic cocainetreated rats compared with baseline. However, EPSC values were significantly $(p<0.01)$ different from those observed with an equivalent concentration of SKF81297 $(1 \mu \mathrm{M})$ in saline-treated/ control rats. Consistent with a $\mathrm{D}_{1 / 5}$ receptor-mediated effect, SCH23390 $(10 \mu \mathrm{M})$, a selective $\mathrm{D}_{1 / 5}$ receptor antagonist, blocked completely the effects of SKF81297 (10 $\mu \mathrm{M})$ (Fig. 6C) (SKF effect in the presence of SCH, $\left.F_{(3,12)}=1.01 ; p>0.05\right)$. Also, SCH23390 $(10 \mu \mathrm{M})$, itself, did not significantly affect EPSCs, suggesting that tonic activation of $\mathrm{D}_{1 / 5}$ receptors by endogenous DA could not account for changes in EPSCs in chronic cocaine-treated rats.

$\mathrm{R} / \mathrm{hCRF}$ (100 $\mathrm{nm}$ ) increased putative BLA-mPFC EPSCs (Fig. 6B), an action not present in saline-treated/controls. EPSC amplitudes after r/hCRF $(12.5,50$ $\mathrm{nM})$ were not significantly different $(p>0.05)$ from those obtained after $\mathrm{r} / \mathrm{hCRF}(12.5,50 \mathrm{nM})$ in saline-treated/controls. These data indicated that in chronic cocaine-treated rats, but not in saline-treated controls, r/hCRF itself increased EPSCs.

To characterize the type of CRF receptor mediating r/hCRFinduced increases in EPSCs, we tested r/hCRF (100 nM) with selective antagonists for $\mathrm{CRF}_{1}$ and $\mathrm{CRF}_{2}$ receptors, $\mathrm{NBI} 30775$ and Ast $_{2} \mathrm{~B}$, respectively. As shown in Figure 6D, NBI30775 (500 nM) did not block the effects of r/hCRF (100 nM) on EPSCs. In addition, NBI30775 (500 nM) by itself did not affect EPSC amplitude. Together these data suggested that $\mathrm{CRF}_{1}$ receptors neither mediated $\mathrm{r} / \mathrm{hCRF}(100 \mathrm{nM})$ effects on EPSCs, nor were activated by endogenous $\mathrm{CRF}$ in chronic cocaine-treated rats. Conversely, Ast $_{2} \mathrm{~B}$ itself significantly depressed EPSCs and blocked the effect of r/hCRF (100 nM) on EPSCs (Fig. 6E). Thus, our data demonstrated that activation of $\mathrm{CRF}_{2}$ receptors by $\mathrm{r} / \mathrm{hCRF}$ applied exogenously or by endogenously released CRF-related peptides facilitated EPSCs in chronic cocaine-treated rats.

$r / h C R F$-facilitated $D_{1 / 5}$ receptor-mediated increase of putative $B L A-m P F C$ EPSCs was synergistically increased when combined with $r / h C R F$

Based on our results (Fig. $2 \mathrm{~A}$ ) showing that DA-mediated depression of $\mathrm{mPFC}$ EPSCs was synergistically enhanced when DA was combined with $\mathrm{r} / \mathrm{hCRF}$ in saline-treated/controls, we also tested for modulatory effects of $\mathrm{D}_{1 / 5}$ receptor ligands combined with $\mathrm{r} / \mathrm{hCRF}$ after chronic cocaine. R/hCRF (50 nM) plus SKF (100 nM or higher concentrations) further enhanced EPSCs (10 $\mathrm{nM}, 99.8 \pm 0.1 \% ; p>0.05 ; 100 \mathrm{nM}, 106.2 \pm 1.1 \% ; p<0.05 ; 1 \mu \mathrm{M}$, $124.8 \pm 2.3 \% ; p<0.05 ; 10 \mu \mathrm{M}, 122.3 \pm 0.1 \%$; $p<0.05)$, indicating that $\mathrm{r} / \mathrm{hCRF}(50 \mathrm{nM})$ synergistically enhanced SKF effects $\left(\mathrm{r} / \mathrm{hCRF} \times \mathrm{SKF}\right.$ concentration effect, $F_{(4,76)}=18.7 ; p<0.01$; $\mathrm{r} / \mathrm{hCRF}$ effect, $F_{(1,19)}=35.0 ; p<0.01$; SKF concentration effect, $\left.F_{(4,76)}=70.2 ; p<0.01 ; n=21\right)$. As shown in Figure $6 A, \mathrm{r} / \mathrm{hCRF}$ shifted the concentration-response for SKF81297 upward and to the left $\left(\mathrm{EC}_{50}=183.6 \mathrm{nM}\right.$ compared with $6.6 \mu \mathrm{M}$ without $\mathrm{r} / \mathrm{hCRF})$, resulting in a $22.3 \%$ facilitation after SKF81297 (10 $\mu \mathrm{M})$ plus $\mathrm{r} / \mathrm{hCRF}(50 \mathrm{nM})$ compared with $14.1 \%$ facilitation after SKF81297 $(10 \mu \mathrm{M})$, suggesting that r/hCRF (50 nM) synergistically enhanced the SKF81297-induced increases of EPSCs in chronic cocaine-treated rats.

We examined the subtypes of DA and CRF receptors involved in the synergistic facilitatory effect of r/hCRF and SKF81297 by testing the combined effects of SKF81297 ( $1 \mu \mathrm{M})$ plus r/hCRF (50 $\mathrm{nM})$ on EPSCs in the presence of selective antagonists for $\mathrm{D}_{1 / 5}$, $\mathrm{CRF}_{1}$, and $\mathrm{CRF}_{2}$ receptors (Fig. $\left.6 C-F\right)$. The concentrations $(1 \mu \mathrm{M}$ SKF81297 plus $50 \mathrm{nM} \mathrm{r} / \mathrm{hCRF}$ ) used to probe for DA and CRF receptor interactions were chosen because each drug lacked significant effects on EPSCs at these concentrations either in salinetreated controls or chronic cocaine-treated rats when tested independently. Thus, if present, changes in EPSCs after SKF81297 
A

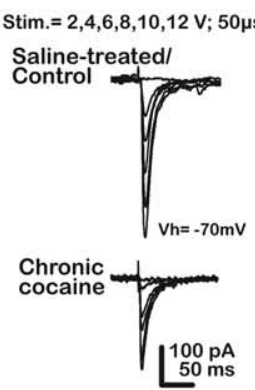

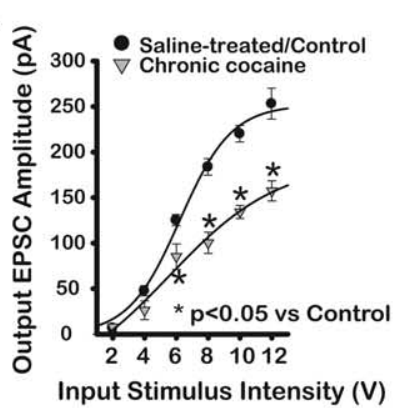

B

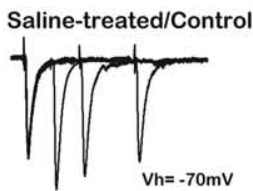

Chronic Cocaine

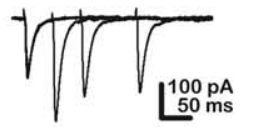

Chronic Cocaine, $\operatorname{TTX} 1 \mu \mathrm{M}$

C Saline-treated/Control, TTX $1 \mu \mathrm{M}$
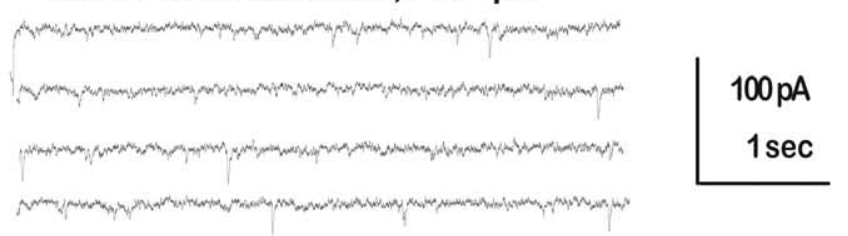

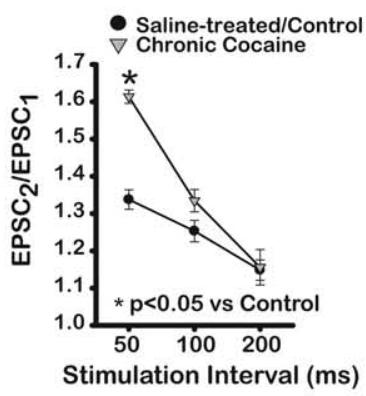

Stimulation Interval (ms)
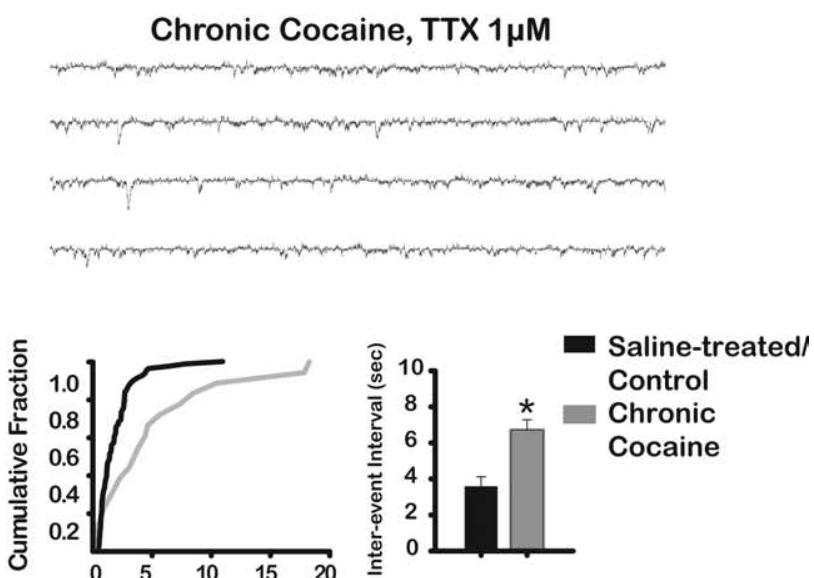

Inter-event Interval (sec)

Figure 5. Chronic cocaine administration affected presynaptic mechanisms to depress putative BLA-mPFC EPSCs and mEPSC frequency but not mEPSC amplitude. $A$, Left, Representative traces of EPSCs evoked at different stimulus intensities from saline-treated rats (top traces) and chronic cocaine-treated rats (bottom traces). Stimulation parameters noted above. Right, EPSC amplitude (in picoamperes) plotted as a function of stimulus intensity (in volts) for each treatment group. EPSCs were significantly reduced in chronic cocaine-treated rats compared with saline-treated rats. $B$, Representative traces of EPSCs evoked by pairs of stimuli at different interstimulus intervals in saline-treated (top traces) and chronic cocaine-treated rats (bottom traces). Right, Paired-pulse ratios $\left(P P R=E P S C_{2} / E P S C_{1}\right)$ plotted as a function of interstimulus interval. PPR values were significantly increased in slices from chronic cocaine-treated rats compared with saline-treated rats. $C$, Representative records of mEPSC activity after TTX (1 $\mu \mathrm{M})$ recorded from mPFC-layer V pyramidal neurons from saline-treated (left traces) and chronic cocaine-treated (right traces) rats. $\boldsymbol{D}$, Cumulative fraction plots for $\mathrm{mEPSC}$ amplitude and interevent intervals calculated from a representative single recording with summary bar graphs. Note that $\mathrm{mEPSCs}$ were only included if they exceeded the preset baseline/noise level (5 pA). After chronic cocaine, mEPSP analyses showed a significant reduction in frequency, but not amplitude.

$(1 \mu \mathrm{M})$ plus $\mathrm{r} / \mathrm{hCRF}(50 \mathrm{nM})$ would likely result from the synergistic action of CRF and DA receptors and their associated mechanisms, rather than from a summation of their individual effects.

As shown in Figure $6 \mathrm{~F}, \mathrm{SCH} 23390$ and $\mathrm{Ast}_{2} \mathrm{~B}$, but not NBI30775, blocked completely the effects of SKF81297 (1 $\mu \mathrm{M})$ plus $\mathrm{r} / \mathrm{hCRF}$ (50 nM) on EPSCs. These data suggested that after chronic cocaine, $\mathrm{CRF}_{2}$ and $\mathrm{D}_{1 / 5}$ receptors mediated the synergistic potentiation of EPSCs by SKF81297 $(1 \mu \mathrm{M})$ plus r/hCRF (50 $\mathrm{nM})$ in chronic cocaine-treated rats. In addition, $\mathrm{CRF}_{1}$ receptors do not contribute to the effects of SKF81297 (1 $\mu \mathrm{M})$ plus r/hCRF (50 nM) in chronic cocaine-treated rats. Thus, based on our findings, there is an apparent loss of function for $\mathrm{CRF}_{1}$ receptors in the modulation of EPSCs after chronic cocaine administration. A similar result was obtained at the lateral septum mediolateral nucleus (LSMLN) synapse after chronic cocaine administration (Liu et al., 2005).

In chronic cocaine-treated rats, DA and $r / h C R F$ synergistically enhanced putative BLA-mPFC EPSCs in the presence of a $D_{2 / 3}$ receptor antagonist

To confirm our findings with SKF81297 and r/hCRF, we tested the endogenous ligand DA $(10 \mu \mathrm{M})$ in combination with $\mathrm{r} / \mathrm{hCRF}$, in the presence of raclopride $(10 \mu \mathrm{M})$, a selective $\mathrm{D}_{2 / 3}$ receptor antagonist (Fig. 7). In slices from cocaine-treated rats, exogenous application of raclopride $(10 \mu \mathrm{M})$, itself, resulted in an increase of
EPSCs, possibly because of the unmasking of a tonic depressant action of $\mathrm{D}_{2 / 3}$ receptors by an elevated endogenous DA (Fig. 7A).

This tonic endogenous depressant effect of $D_{2 / 3}$ receptors on EPSCs unmasked by raclopride (raclopride, $131.3 \pm 2.6 ; p<$ 0.05 ; after washout, $122.7 \pm 8.3 ; p>0.05 ; F_{(2,6)}=13.46 ; p<$ 0.05 ) in chronic cocaine-treated rats was not blocked by loading pyramidal neurons with GDP $\beta$ S (data not shown), suggesting a presynaptic location for tonically active $\mathrm{D}_{2 / 3}$ receptors in chronic cocaine-treated animals. After raclopride $(10 \mu \mathrm{M})$, exogenous application of DA $10 \mu \mathrm{m}$ further increased EPSCs in a significant and reversible manner (DA effect, $F_{(2,8)}=10.2 ; p<0.01$ ). In addition, coapplication of DA $(10 \mu \mathrm{M})$ with $\mathrm{r} / \mathrm{hCRF}(50 \mathrm{nM})$ enhanced DA effects on EPSCs (DA-control, $12.2 \%$ increase; DA plus $\mathrm{r} / \mathrm{hCRF}, 25.4 \%$ increase) (Fig. $7 A, B$ ) (DA plus $\mathrm{r} / \mathrm{hCRF}$, $125.4 \pm 1.2 \% ; p<0.01$; washout, $99.1 \pm 3.4 \% ; p>0.05$; $\mathrm{r} / \mathrm{hCRF} \times \mathrm{DA}$ concentration, $F_{(2,16)}=7.36 ; p<0.01 ; \mathrm{r} / \mathrm{hCRF}$ effect, $F_{(1,8)}=5.33 ; p<0.01$; DA effect, $F_{(2,16)}=55.5 ; p<0.01$; $n=10)$. The increases in EPSC amplitude by DA alone and the combination of DA plus CRF occurred independent of any significant postsynaptic change as monitored continuously as input conductance (Fig. 7B). These data with DA and raclopride confirmed our findings with SKF81297 and demonstrated that $\mathrm{r} / \mathrm{hCRF}$ acted synergistically to enhance $\mathrm{D}_{1 / 5}$ receptor-mediated facilitating effects on EPSCs in chronic cocaine-treated rats. 


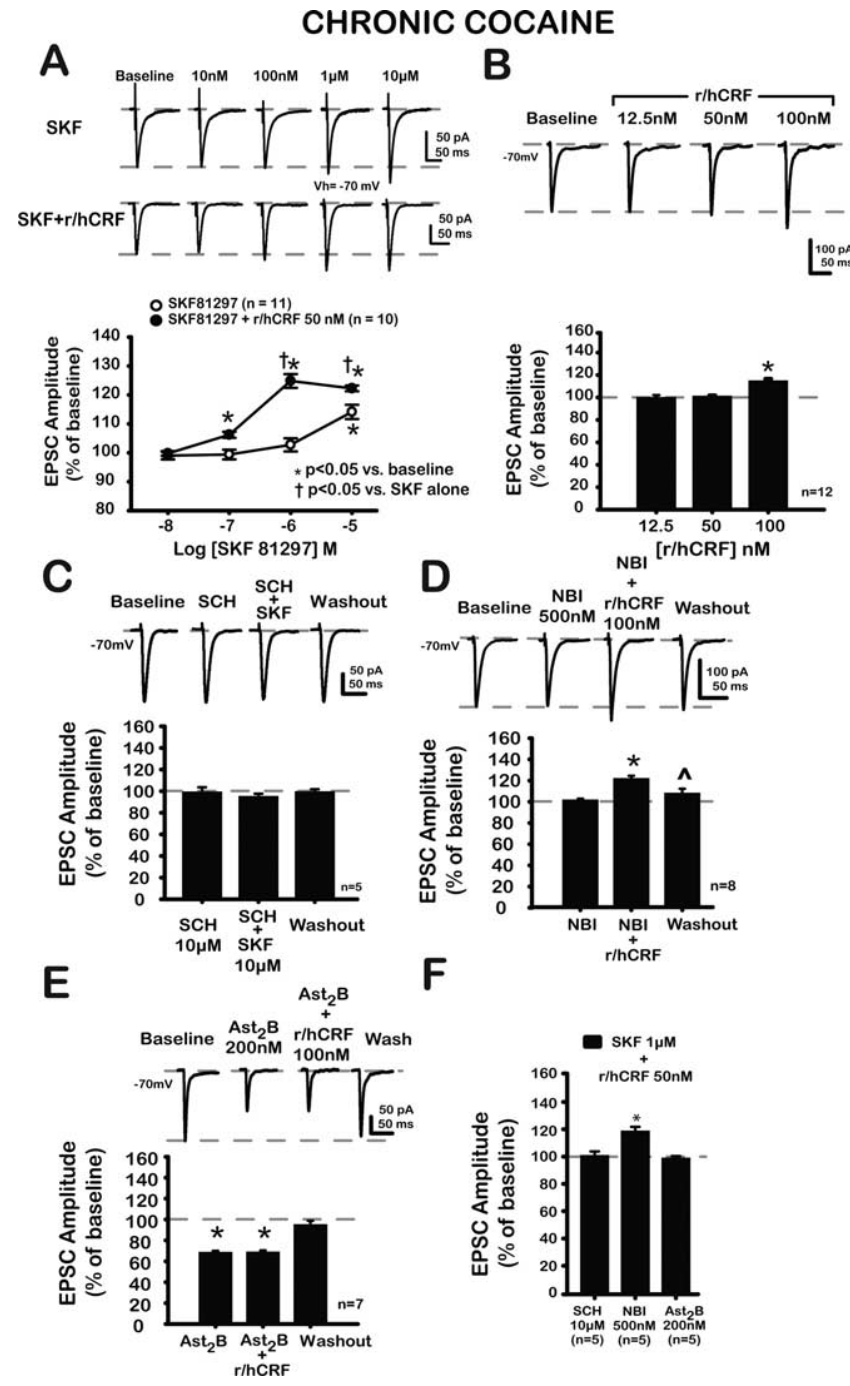

Figure 6. Actions of SKF alone, in combination with $\mathrm{r} / \mathrm{hCRF}$, with $\mathrm{r} / \mathrm{hCRF}$ alone, and with antagonists were altered after chronic cocaine administration. $A$, Representative traces of EPSCS at baseline, after increasing concentrations of SKF (top traces), and SKF plus r/hCRF (50 nM; bottom traces). Bottom, Concentration-response curves for each treatment group. SKF (10 $\mu \mathrm{M})$ significantly increased EPSCS (114.1 $\pm 2.5 \%)$. Lower concentrations of SKF did not affect EPSCS, indicating that $\mathrm{r} / \mathrm{hCRF}(50 \mathrm{~nm})$ synergistically enhanced SKF effects. $\boldsymbol{B}$, Representative traces of EPSCs at baseline and after $r / h C R F(12.5,50,100 \mathrm{~nm})$. R/hCRF (100 nM) significantly increased EPSC amplitude (115.0 $\pm 1.2 \% ; p<0.01)$. Lower concentrations of $r / h C R F(12.5,50 \mathrm{~nm})$ did not have a significant effect on EPSC amplitude (12.5 nM, $99.3 \pm 1.3 \% ; p>0.05 ; 100.9 \pm$ $1.1 \% ; p>0.05)$. C, Representative traces of EPSCs at baseline, after SCH (10 $\mu \mathrm{M})$, after SCH (10 $\mu \mathrm{M})$ plus SKF $(10 \mu \mathrm{M})$, and after $20 \mathrm{~min}$ washout. Summary data are shown in bar graph below. SCH $(10 \mu \mathrm{m})$ did not have a significant effect on EPSCS $(99.4 \pm 4.2 \% ; p>0.05)$. SCH $(10 \mu \mathrm{m})$ blocked the effects of SKF $(10 \mu \mathrm{m}, 95.3 \pm 2.4 \%$ after SCH plus SKF; $p>0.05 ; 99.6 \pm 2.0 \%$ after washout; $p>0.05)$. D, Representative traces of EPSCs at baseline after NBI (500 nM), after $\mathrm{r} / \mathrm{hCRF}(100 \mathrm{~nm})$ plus NBI ( $500 \mathrm{~nm})$, and after 20 min washout. Summary data are shown in bar graph below. NBI (500 nM) did not affect EPSCs (101.9 $\pm 0.9 \%$; paired $t=-2.02 ; p>0.05)$, and NBI ( $500 \mathrm{~nm})$ did not block the effects of $\mathrm{r} / \mathrm{hCRF}\left(100 \mathrm{~nm} ; \mathrm{r} / \mathrm{hCRF}\right.$ effect, $F_{(3,21)}=58.99 ; p<$ 0.01 ) on EPSCs (122.1 $\pm 1.7 \%$ after $500 \mathrm{~nm} \mathrm{NBI}$ plus $100 \mathrm{~nm} \mathrm{r} / \mathrm{hCRF} ; p<0.01 ; 108.3 \pm 2.3 \%$ after washout; $p>0.05)$. E, Representative traces of EPSCs at baseline, after Ast $_{2} B(200 \mathrm{~nm})$, after $r / h C R F(100 \mathrm{~nm})$ plus $A s t_{2} B$, and after 20 min washout. Summary data are illustrated in bar graph below. Ast ${ }_{2} B$ itself depressed EPSCs (68.8 $\pm 1.2 \%$; Ast $_{2} B$ effect, $F_{(3,18)}=144.4 ; p<$ 0.01 ) and blocked $r / h C R F\left(100 \mathrm{~nm}\right.$ ) effects on EPSCs (Ast ${ }_{2} B$ plus $r / h C R F, 69.1 \pm 0.1 \% ; p>0.05$ compared with $A_{2}{ }_{2} B$ alone). $\boldsymbol{F}$, Bar graph summarizes the effects of selective antagonists for $D_{1 / 5}(S C H, 10 \mu \mathrm{M}), C R F_{1}(N B I, 500 \mathrm{~nm})$, and $\mathrm{CRF}_{2}\left(\mathrm{Ast}_{2} \mathrm{~B}, 200 \mathrm{~nm}\right)$ receptors on the effects of combined agonists. Ast $\mathrm{B}$ and $\mathrm{SCH}$ blocked the effects of the combined agonists on EPSCS (SCH plus r/hCRF plus SKF, $100.8 \pm 2.7 \%$; paired $t=0.30 ; p>0.05 ;$ Ast $_{2} \mathrm{~B}$ plus $\mathrm{r} / \mathrm{hCRF}$ plus SKF, $98.9 \pm 1.3 \%$; paired $t=0.85 ; p>0.05)$. NBI ( $500 \mathrm{~nm}$ ) was unable to block the effects of the combined agonists (118.5 $\pm 2.9 \% ; p<0.05$ compared with baseline; $t=1.6 ; p>0.05$ compared with SKF plus $r / h(R F) .{ }^{*} p<0.05$ versus baseline.

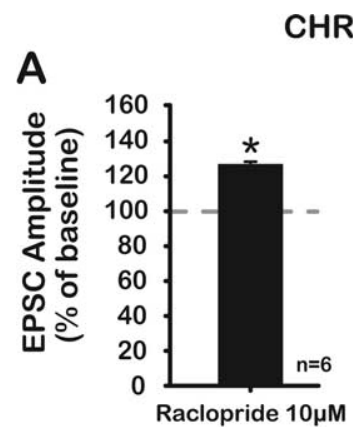

CHRONIC COCAINE

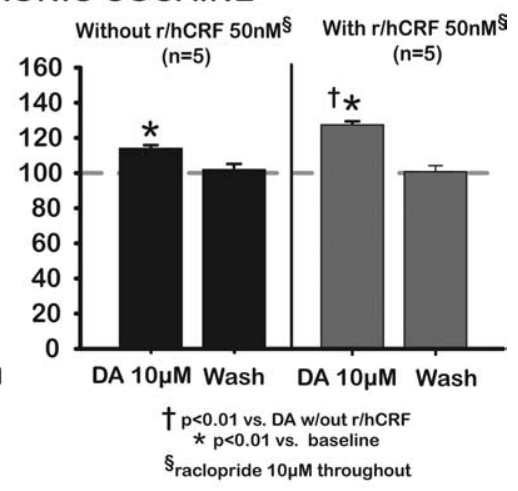

B
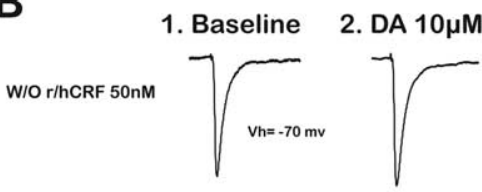

3. Washout
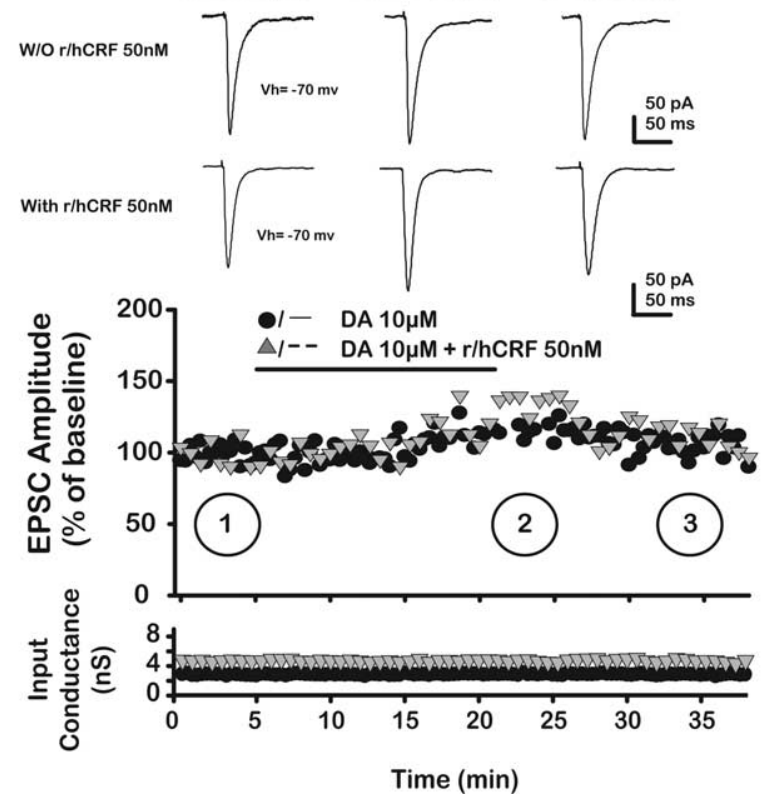

Figure 7. R/hCRF facilitated a DA-mediated increase of putative BLA-mPFC EPSCs in the presence of raclopride, a $\mathrm{D}_{2 / 3}$-like antagonist, in chronic cocaine-treated rats. $A$, Left, Application of raclopride $(10 \mu \mathrm{m}), \mathrm{aD}_{2}$-like antagonist, unmasked tonic inhibitory action of $\mathrm{D}_{2 / 3}$ receptors at the synapse, thus increasing EPSCS (127.0 $\pm 1.4 \%$; paired $t=-19.17 ; p<0.05)$. Right, DA (10 $\mu \mathrm{M})$ caused a significant increase of EPSCs $(112.2 \pm 1.8 \% ; p<0.01)$, which returned to baseline (100.1 $\pm 3.1 \%$ after 20 min washout; $p>0.05$ when compared with baseline with raclopride). R/hCRF (50 nM) enhanced DA (10 $\mu \mathrm{m})$ effects on EPSCs. Note that raclopride $(10 \mu \mathrm{m})$ is present throughout. $\boldsymbol{B}$, Plots depict amplitude of EPSCS (percentage of baseline) as a function of time in each treatment group. Top, Representative averaged traces of EPSCs taken at different time points, indicated by numbers. Bottom, Input conductance is plotted as a function of time.

$C R F_{2}$ and $D_{1 / 5}$ receptors mediating the effects of $r / h C R F$ and DA ligands in chronic cocaine-treated rats are located presynaptically To determine the location of $\mathrm{CRF}_{2}$ and $\mathrm{D}_{1 / 5}$ receptors at the putative BLA-mPFC synapse after treatment with chronic cocaine, voltage-clamped pyramidal neurons were loaded with GDP $\beta$ S (1 mM) before testing the effects of $\mathrm{r} / \mathrm{hCRF}$, SKF81297, or the combination on EPSCs. The effectiveness of GDP $\beta$ S was assayed as described previously (Fig. $3 A)$. GDP $\beta$ S ( $1 \mathrm{mM}$ ) did not block the effects of $\mathrm{r} / \mathrm{hCRF}(100 \mathrm{nM} ; 120.1 \pm 1.45 \%$; paired $t=$ $-13.13 ; p<0.01 ; n=5)$, SKF $(10 \mu \mathrm{M} ; 119.9 \pm 1.5 \%$; paired $t=$ $-13.11 ; p<0.01 ; n=5)$, or the combination $(117.3 \pm 2.8 \%$; paired $t=-6.2 ; p<0.01 ; n=5$ ) on EPSCs. EPSCs from neurons loaded with GDP $\beta$ S were not different from those obtained from neurons without GDP $\beta$ S (100 nM r/hCRF, $t=2.40 ; p>0.05 ; 10$ 
A CHRONIC COCAINE

B

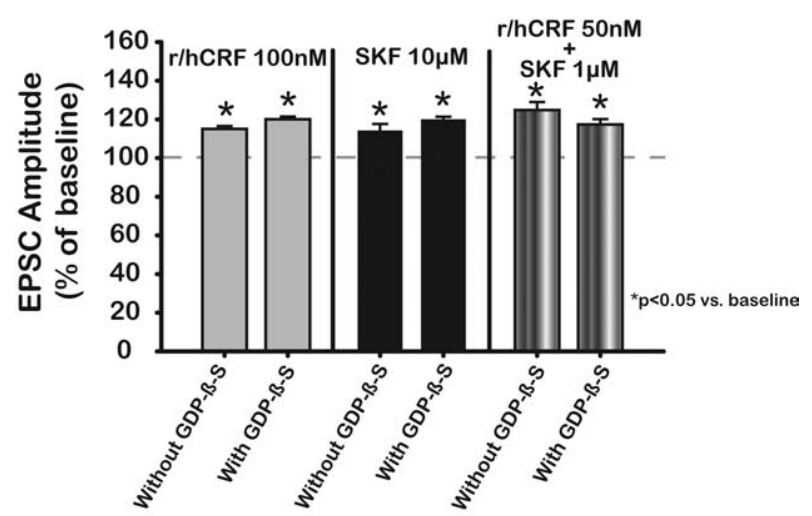

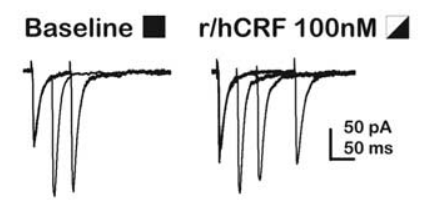

Baseline

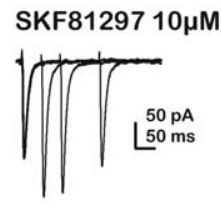

SKF $1 \mu \mathrm{M}$

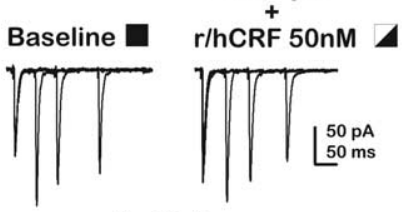

$\mathrm{Vh}=-70 \mathrm{mV}$

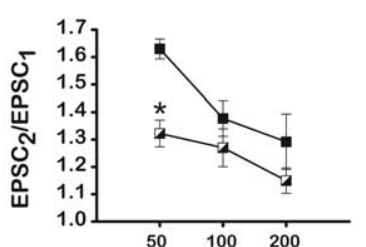

$50 \quad 100 \quad 200$
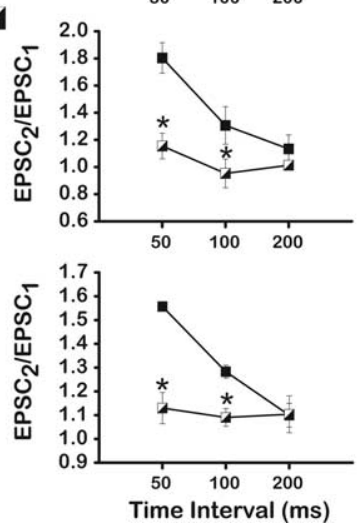

Figure 8. Presynaptic $C_{2 F}$ and $D_{1 / 5}$ receptors interact to increase putative $B L A-m P F C E P S C S$ in chronic cocaine-treated rats. $A$, Bar graph summarizes the effects of $\mathrm{r} / \mathrm{hCRF}(100 \mathrm{~nm})$, SKF (10 $\mu \mathrm{M}$ ), and a combination (50 nм r/hCRF plus $1 \mu \mathrm{M}$ SKF) on EPSCs recorded from mPFC-layer V pyramidal neurons loaded with GDP $\beta S(1 \mathrm{~mm})$ from chronic cocaine-treated rats. Data from neurons without GDP $\beta$ S are included for comparison. Vertical solid lines divide the data for each drug-treatment group. GDP $\beta S$ (1 mM) did not block the effects of the individual ligands or their combination. $\boldsymbol{B}$, Representative traces of EPSCs evoked by pairs of stimuli at different interstimulus intervals at baseline (left column) and after $\mathrm{r} / \mathrm{hCRF}$ (100 nm; right column, top traces), SKF (10 $\mu \mathrm{m}$; right column, middle traces), and the combination ( $50 \mathrm{~nm} \mathrm{r} / \mathrm{hCRF}$ plus $1 \mu \mathrm{m}$ SKF). Right, Paired-pulse ratios (PPR $=$ EPSC $_{2} /$ EPSC $_{1}$ ) plotted as a function of interstimulus interval for each treatment group. PPR values were decreased significantly by $\mathrm{r} / \mathrm{hCRF}(100 \mathrm{~nm})$ compared with baseline only at the shortest interval ( $50 \mathrm{~ms}$ ).

$\mu \mathrm{M}$ SKF, $t=-1.49 ; p>0.05$; the combination, $t=-1.43 ; p>$ 0.05) (Fig. 8A).

To validate these findings, we conducted paired-pulse experiments (50, 100, and $200 \mathrm{~ms}$ interstimulus intervals) (Fig. 8B). $\mathrm{R} / \mathrm{hCRF}(100 \mathrm{nM}), \mathrm{SKF} 81297(10 \mu \mathrm{M})$, and the combination 50 $\mathrm{nm}$ r/hCRF plus $1 \mu \mathrm{M}$ SKF81297 consistently decreased PPR values compared with baseline values at $50 \mathrm{~ms}(1.63 \pm 0.0 .04$ vs $1.32 \pm 0.05 ; p<0.01)$. Less consistent were the effects of these compounds on PPR values measured at 100 and $200 \mathrm{~ms}$ interstimulus intervals (Fig. 8 B) $(100 \mathrm{~ms}, 1.38 \pm 0.07$ vs $1.27 \pm 0.07$; $p>0.05 ; 200 \mathrm{~ms}, 1.29 \pm 0.1$ vs $1.15 \pm 0.05 ; p>0.05 ; \mathrm{r} / \mathrm{hCRF}$ effect, $\left.F_{(1,4)}=64.44 ; p<0.01 ; n=5\right)$. PPR values were decreased significantly by SKF $(10 \mu \mathrm{M})$ compared with baseline only at the

two shorter intervals ( $50 \mathrm{~ms}, 1.80 \pm 0.11$ vs $1.15 \pm 0.09 ; p<0.05$; $100 \mathrm{~ms}, 1.31 \pm 0.14$ vs $0.95 \pm 0.11 ; p<0.05 ; 200 \mathrm{~ms}, 1.13 \pm 0.1$ vs $1.01 \pm 0.04 ; p>0.05$; SKF effect, $F_{(1,4)}=215.82 ; p<0.01 ; n=$ $5)$. PPR with the combination $50 \mathrm{nM} \mathrm{r} / \mathrm{hCRF}$ plus $1 \mu \mathrm{M}$ SKF was similarly reduced when compared with baseline (50 ms, $1.56 \pm$ 0.02 vs $1.13 \pm 0.07 ; p<0.01 ; 100 \mathrm{~ms}, 1.28 \pm 0.03$ vs $1.09 \pm 0.04$; $p<0.05 ; 200 \mathrm{~ms}, 1.10 \pm 0.05$ vs $1.10 \pm 0.08 ; p>0.05 ; 50 \mathrm{nM}$ $\mathrm{r} / \mathrm{hCRF}$ plus $1 \mu \mathrm{M}$ SKF effect, $\left.F_{(1,4)}=96.05 ; p<0.01 ; n=5\right) .{ }^{\star} p<$ 0.05 versus baseline.

These results suggested that $\mathrm{CRF}_{2}$ and $\mathrm{D}_{1 / 5}$ receptors are located presynaptically in chronic cocaine-treated rats and differed from those obtained in saline-treated controls (Fig. 1).

In addition, comparison of data, not shown but collected after chronic cocaine administration, demonstrated that EPSCs recorded in the presence of raclopride are still significantly depressed $(149.4 \pm 6.5 \mathrm{pA} ; p<0.003)$ relative to EPSCs recorded from saline-treated neurons $(205.8 \pm 12.9 \mathrm{pA})$.

Similarly, EPSCs recorded in the presence of Astressin ${ }_{2} B$ from neurons collected after chronic cocaine administration are depressed significantly $(143.7 \pm 14.9 \mathrm{pA} ; p<0.04)$ relative to EPSCs recorded from saline-treated neurons $(210.1 \pm 24.7)$. These results support the concept of a chronic cocaine-induced tonic regulation of EPSCs by $\mathrm{CRF}_{2}$ and $\mathrm{D}_{2}$-like receptors, respectively, after chronic cocaine administration (Fig. 9).

\section{Discussion}

\section{Experiments in saline-treated/control rats}

We provide evidence for an interaction between DA and $\mathrm{r} / \mathrm{hCRF}$ on glutamatergic synaptic transmission at a critical synapse carrying input from the basolateral amygdala to the prelimbic prefrontal cortex. The results demonstrated a novel process through which increased CRF, as might occur after a stressor, potentiates an ongoing modulation of excitatory transmission by DA. Specifically, we showed that a concentration-dependent $D_{1 / 5}$ receptor activation depressed EPSCs (Fig. 1) and localized these receptors with GDP $\beta S$ and PPR analyses (Figs. 3, 9) to both presynaptic and postsynaptic sites. Although demonstrating similar concentration sensitivity, these results differ from Onn et al. (2006), who report that $\mathrm{D}_{1 / 5}$ receptor activation facilitated corpus callosum afferent to type I mPFC (including the anterior cingulate, $\mathrm{Cg} 3$ area, and prelimbic cortex) pyramidal neuron EPSCs. Our findings that DA or SKF81297 depressed mPFC EPSCs are consistent with previous reports of presynaptic $\mathrm{D}_{1 / 5}$ receptors in the mPFC (Law-Tho et al., 1994; Momiyama et al., 1996; Gao et al., 2001; Urban et al., 2002; Paspalas and Goldman-Rakic, 2004; Mair and Kauer, 2006), and also support a postsynaptic locus for $\mathrm{D}_{1 / 5}$ receptors. $\mathrm{D}_{1 / 5}$ receptors enhance NMDA EPSCs (Zheng et al., 1999; Seamans et al., 2001a; Wang and O'Donnell, 2001; Tseng and O'Donnell, 2004), while having only a small or no effect on non-NMDA EPSCs. Because putative BLA-mPFC EPSCs lack a significant NMDA component (Orozco-Cabal et al., 2006a), our results indicated a significant $D_{1 / 5}$ effect mediated through non-NMDA receptors. R/hCRF ( $\leq 100 \mathrm{~nm}$ ) (Fig. $1 C$ ) alone did not have a significant effect on EPSCs, consistent with results in ventral tegmental DA neurons, in which $\mathrm{r} / \mathrm{hCRF}$ did not affect non-NMDA EPSCs (Ungless et al., 2003). However, $\mathrm{r} / \mathrm{hCRF}\left(50 \mathrm{~nm}\right.$ ) acted through postsynaptic $\mathrm{CRF}_{1}$ receptors (Figs. $2,3,9)$ to enhance EPSC depression induced by coapplied $D_{1 / 5}$ receptor agonists. Synergistic EPSC depression by a combined activation of postsynaptic $\mathrm{CRF}_{1}$ and $\mathrm{D}_{1 / 5}$ receptors has not been reported previously but may be caused by activation and retrograde release of substances acting presynaptically and/or the modulation of an adjacent, third receptor type, e.g., metabo- 


\section{PUTATIVE Glutamatergic-BLA to mPFC Synapse}

\section{SALINE-TREATED/CONTROLS}

\section{BLA Terminal}

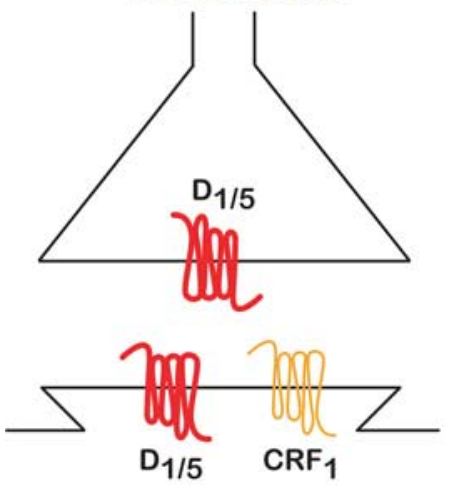

PL-layer V pyramidal neuron

\section{CHRONIC COCAINE}

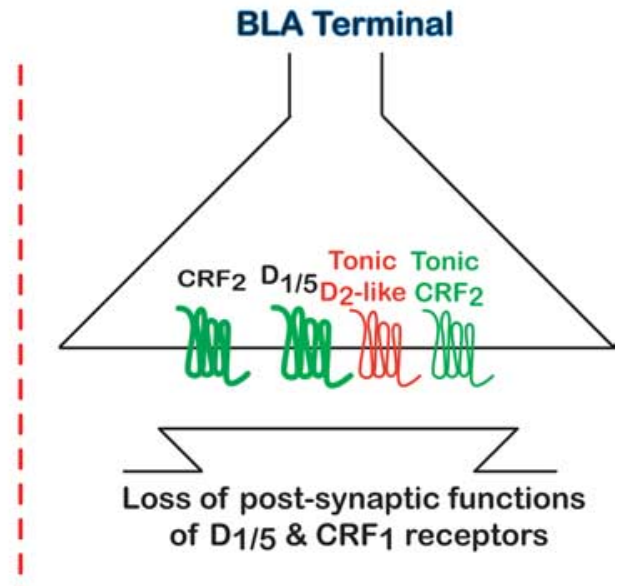

PL-layer V pyramidal neuron
Figure 9. The type and function of CRF and DA receptors at the putative BLA-mPFC synapse were different in saline-treated controls compared with chronic cocaine-treated rats. Left, Activation of presynaptic and postsynaptic $D_{1 / 5}$ receptors in salinetreated/control rats decreased EPSCs (inhibitory effect; red). Activation of postsynaptic CRF 1 receptors (orange) by $\mathrm{r} / \mathrm{hCRF}$ in the presence of glutamate and $\mathrm{D}_{1 / 5}$ agonists further depressed $E P S C$. In addition, no tonic modulatory effects for $\mathrm{D}_{1 / 5}, \mathrm{CRF}_{1}$, or $\mathrm{CRF}_{2}$ receptors were measurable in saline-treated/controls. Right, After chronic cocaine administration, activation of presynaptic $D_{1 / 5}$ receptors increased cocaine-induced depressed EPSCS. Moreover, activation of presynaptic CRF, receptors, unmasked by chronic cocaine administration, led to EPSC enhancement. Furthermore, a synergistic interaction by coactivation of these receptors with low concentrations of $\mathrm{r} / \mathrm{hCRF}$ and $\mathrm{D}_{1 / 5}$ agonists increased EPSC amplitude to values greater than occurred after activation of either receptor independently. On the other hand, $\mathrm{CRF}_{1}$ and $\mathrm{D}_{1 / 5}$ postsynaptic receptor functions were lost in chronic cocaine-treated rats. Our results also revealed a tonic facilitatory and depressant effect for $\mathrm{CRF}_{2}$ and $\mathrm{D}_{2}$-like receptors (shaded), respectively, that was unmasked after chronic cocaine administration. Thus, there was an apparent switch in the function of presynaptic $D_{1 / 5}$ receptors along with a novel facilitatory effect for presynaptic $C_{2} F_{2}$ receptors. Tonic inhibitory activation of presynaptic $D_{2 / 3}$ receptors may also contribute to depression of synaptic transmission within this putative BLA-mPFC synapse after chronic cocaine administration.

tropic glutamate receptor (Ohno-Shosaku et al., 2002) or cannabinoid receptor (Melis et al., 2004).

Our data also demonstrated that $\mathrm{r} / \mathrm{hCRF}$ alone or in combination with $\mathrm{D}_{1 / 5}$ receptor agonists does not affect $\mathrm{GABA}_{\mathrm{A}}$ receptor-mediated IPSCs in slices from either saline- or cocainetreated animals (supplemental Fig. 1, available at www.jneurosci.org as supplemental material).

The concentrations of $\mathrm{r} / \mathrm{hCRF}$ used in these studies are within physiological (endogenous) ranges. Based on our previous studies demonstrating significant effects of $\mathrm{r} / \mathrm{hCRF}$ on EPSCs in limbic structures related to the PFC (Liu et al., 2004; Pollandt et al., 2006), concentrations of $\mathrm{r} / \mathrm{hCRF}<100 \mathrm{~nm}$ were used here. Low nanomolar concentrations of $\mathrm{r} / \mathrm{hCRF}$ closely mimic CRF concentrations $(0.3 \mathrm{~nm})$ reported for the amygdala after acute withdrawal from chronic cocaine administration (Richter et al., 1995; Merlo et al., 1995; Richter and Weiss, 1999). Also, comparable endogenous levels of CRF outside the hypothalamic-pituitaryadrenal axis have been reported in human plasma and CSF, respectively (Catalan et al., 1998; Baker et al., 1999).

\section{Experiments in chronic cocaine-treated rats}

Electrical and synaptic properties of mPFC-layer $V$ pyramidal neurons

Electrical membrane properties at layer $\mathrm{V}$ prelimbic pyramidal neurons were different in chronic cocaine-treated rats compared with saline-treated controls (Table 1). The combination of depolarized membrane potential with increased input resistance would provide a more excitable state for these neurons. Our find- ings of increased input resistance values are consistent with previous reports for mPFC-layer V/VI pyramidal neurons after repeated cocaine administration despite differences in cocaine regimens, withdrawal periods, and recording techniques (Trantham et al., 2002; Nasif et al., 2005a,b).

EPSCs in the chronic cocaine-treated group were depressed compared with saline-treated controls (Fig. 5A). Pairedpulse experiments (Fig. $5 B$ ) and analyses of mEPSCs (Fig. 5C,D) suggested that EPSC depression was attributable to a reduction in glutamate release at BLA terminals. This reduction could result from cocaine-induced changes in modulatory systems regulating glutamate release at BLA terminals [e.g., autoreceptors (mGluRs) (Martin et al., 2007), heteroreceptors (DA) (Chen et al., 2007), associated signaling mechanisms (Bergson et al., 2003), or ligands (adenosine) (Steketee, 2005; Ladera et al., 2007)]. The finding (Fig. $7 A$ ) that presynaptic $\mathrm{D}_{2 / 3}$ receptors exert a tonic inhibitory effect on EPSCs suggests that this mechanism may contribute to depressed EPSCs in the chronic cocaine group.

In human cocaine addicts or animals exposed to cocaine, several studies using gambling tasks and reversal learning paradigms show that outcome-dependent decision processes are defective (Bechara and Damasio, 2002; Schoenbaum et al., 2006). Stalnaker et al. (2007) demonstrated that these deficits relate to persistent encoding of outdated associative information in the BLA. Our findings suggest that synaptic depression between the BLA and prelimbic pyramidal neurons might also contribute to abnormal processing of drug-related information leading to biased decision-making processes. Synaptic depression may reduce the dynamic range of BLA-to-mPFC synapse, thus limiting information processing. In fact, this hypothesis is in agreement with recent observations of congruent and abnormal metabolic activity after chronic cocaine administration in the PFC and temporal lobe structures such as the amygdala using a nonhuman primate cocaine-self administration model (Beveridge et al., 2006). The subsequent reversal in polarity of the actions of DA and CRF after chronic cocaine may be an adaptive process to compensate for the synaptic depression associated with chronic cocaine administration.

\section{Modulatory effect of $C R F$ and $D A$ receptors on putative} BLA-mPFC EPSCs

Exogenous r/hCRF (Fig. $6 B, D$ ) or endogenous CRF-related peptides (after $\mathrm{Ast}_{2} \mathrm{~B}$ ) (Fig. $6 \mathrm{E}$ ) increased EPSCs in chronic cocainetreated rats via $\mathrm{CRF}_{2}$ receptors (not detected in recordings from saline-treated/control slices). Unmasking of this presynaptic $\mathrm{CRF}_{2}$ receptor facilitatory function after chronic cocaine was similar to the previously reported occurrence of a $\mathrm{CRF}_{2}$ receptormediated facilitation at the LSMLN after chronic cocaine (Liu et al., 2005). Our findings do not support a role for postsynaptic $\mathrm{CRF}_{1}$ receptors in the modulation of EPSCs by $\mathrm{r} / \mathrm{hCRF}$ alone or combined with DA receptor ligands in chronic cocaine-treated 
rats. This loss of function for postsynaptic $\mathrm{CRF}_{1}$ receptors in $\mathrm{mPFC}$ neurons after chronic cocaine is an illustration of the dynamic changes in CRF systems in response to chronic cocaine administration (cf. Liu et al., 2005). After chronic cocaine administration, a prominent PKA signaling process evident in salinetreated/control slices was reduced with a dominance of PKC signaling (Liu et al., 2005).

Importantly, stress levels have been shown to modulate the behavioral effects of $\mathrm{CRF}_{2}$ receptor activation (Henry et al., 2006), suggesting that "emotional states" may influence the function of CRF systems in the brain. We propose that as endogenous CRF concentrations change as a result of various stressors (e.g., mental disorders, including cocaine addiction), modulation of synaptic transmission by CRF receptors will be affected (OrozcoCabal et al., 2006b; Gallagher et al., 2008). For example, unlike in saline-treated rats, postsynaptic $\mathrm{CRF}_{1}$ receptors did not play a role in the modulation of EPSCs by $\mathrm{r} / \mathrm{hCRF}$ alone or combined with DA receptor ligands in chronic cocaine-treated rats.

The changes in CRF receptor modulation affecting putative BLA-mPFC EPSCs may be related to adaptations initiated during chronic cocaine administration, such as persistently elevated CRF levels. For example, CRF-like immunoreactivity is increased in the PFC during protracted withdrawal from cocaine-binge sessions in rats trained to self-administer cocaine, suggesting that delayed increases in CRF-like immunoreactivity "may reflect a subsequent failure to shut down compensatory CRF-mRNA synthesis" (Zorrilla et al., 2001). Their studies suggested that a massive overflow of CRF in the PFC could lead to CRF receptor changes, including upregulation of $\mathrm{CRF}_{2}$ and downregulation of $\mathrm{CRF}_{1}$ receptors.

In our studies, activation of presynaptic $\mathrm{D}_{1 / 5}$ receptors increased EPSCs in chronic cocaine-treated rats (Fig. 6), and this facilitatory effect was enhanced by activating presynaptic $\mathrm{CRF}_{2}$ receptors. Also, SKF81297, r/hCRF, and the combination decreased PPR values, suggesting that presynaptic $D_{1 / 5}$ as well as $\mathrm{CRF}_{2}$ receptors increased glutamate release from BLA terminals. Interestingly, the effects of the combined agonists could be blocked completely by either SCH23390 or Ast ${ }_{2} \mathrm{~B}$, suggesting that coactivation of $D_{1 / 5}$ and $C R F_{2}$ receptors was required to increase EPSCs at these concentrations. These findings suggest that synergism between $\mathrm{CRF}_{2}$ and $\mathrm{D}_{1 / 5}$ receptors at BLA terminals may arise via one or more mechanisms, e.g., obligate cooperativity between two different receptors (Levenson, 2006), activation of one or the other receptors by a heterodimer of DA (Franco et al., 2007) and CRF (Milan-Lobo et al., 2006), involvement of common signaling pathways (Hillhouse and Grammatopoulos, 2006; Tseng and O'Donnell, 2004), etc. Importantly, these data also show that $\mathrm{D}_{1 / 5}$ receptor modulatory effects are changed in polarity from inhibitory (saline/controls) to facilitatory (chronic cocaine) at this synapse.

Postsynaptic $\mathrm{D}_{1 / 5}$ receptors did not appear to play a significant role in the modulation of putative BLA-mPFC EPSC in chronic cocaine-treated rats, whereas in saline-treated/control rats, an interaction between postsynaptic $\mathrm{CRF}_{1}$ and $\mathrm{D}_{1 / 5}$ receptors was evident. The lack of postsynaptic $\mathrm{D}_{1 / 5}$ receptor-mediated effects after chronic cocaine may be related to $\mathrm{CRF}_{1}$ and/or $\mathrm{D}_{1 / 5}$ receptor dysfunction. Alternatively, these observations may result from a decrease in overall function of $\mathrm{D}_{1 / 5}$ receptors after chronic cocaine administration. Stanwood and Levitt (2007) reported that prenatal exposure to cocaine resulted in substantially reduced $D_{1}$-like receptor coupling to $G(s)$-protein, and $D_{1}$-like receptor responsiveness was related to a reduced cell-surface localization of $\mathrm{D}_{1}$-like receptors. In addition, depressed $\mathrm{D}_{1 / 5}$ receptor func- tion in the dorsomedial PFC has been suggested to explain the cocaine sensitization in rats after repeated administration of cocaine (Sorg et al., 1997), an effect that may contribute to the observed increase in behavioral responses (Ragozzino, 2002).

In summary, our results suggest that coactivation of CRF and DA receptors modulate putative BLA-mPFC EPSCs (Fig. 9). In saline-treated controls, $\mathrm{CRF}$ and $\mathrm{DA}$ receptor activation produced a net inhibitory effect on EPSCs. However, in chronic cocaine-treated rats, CRF and DA receptor activation caused the opposite effect (increased EPSCs). Interestingly, the enhancing effects of presynaptic $\mathrm{D}_{1 / 5}$ and $\mathrm{CRF}_{2}$ receptors coincide with a depression of EPSCs associated with chronic cocaine administration, per se. Perhaps, changes in CRF and DA function reflect compensatory processes at the synaptic level as an attempt to sustain normal communication during a stressful state.

\section{References}

Ambrosio E, Sharpe LG, Pilotte NS (1997) Regional binding to corticotropin releasing factor receptors in brain of rats exposed to chronic cocaine and cocaine withdrawal. Synapse 25:272-276.

Andrade R, Malenka RC, Nicoll RA (1986) A G protein couples serotonin and $G A B A B$ receptors to the same channels in hippocampus. Science 234:1261-1265.

Baker DG, West SA, Nicholson WE, Ekhator NN, Kasckow JW, Hill KK, Bruce AB, Orth DN, Geracioti Jr TD (1999) Serial CSF corticotropinreleasing hormone levels and adrenocortical activity in combat veterans with posttraumatic stress disorder. Am J Psychiatry 156:585-588.

Bechara A, Damasio H (2002) Decision-making and addiction (part 1): impaired activation of somatic states in substance dependent individuals when pondering decisions with negative future consequences. Neuropsychologica 40:1675-1689.

Ben-Shahar O, Keeley P, Cook M, Brake W, Joyce M, Nyffeler M, Heston R, Ettenberg A (2007) Changes in levels of D1, D2, or NMDA receptors during withdrawal from brief or extended daily access to IV cocaine. Brain Res 1131:220-228.

Bergson G, Levenson R, Goldman-Rakic PS, Lidow MS (2003) Dopaminereceptor interacting proteins: the $\mathrm{Ca}(2+)$ connection in dopamine signaling. Trends Pharmacol Sci 24:486-492.

Berridge KC (2007) The debate over dopamine's role in reward: the case for incentive salience. Psychopharmacology (Berl) 191:391-431.

Beveridge TJR, Smith HR, Daunais JB, Nader MA, Porrino LJ (2006) Chronic cocaine self-administration is associated with altered functional activity in the temporal lobes of non-human primates. Eur J Neurosci 23:3109-3118.

Catalan R, Gallart JM, Castellanos JM, Galard R (1998) Plasma corticotropin-releasing factor in depressive disorders. Biol Psychiatry 44: 15-20.

Cepeda C, Radisavljevic Z, Peacock W, Levine MS, Buchwald NA (1992) Differential modulation by dopamine of responses evoked by excitatory amino acids in human cortex. Synapse 11:330-341.

Chen G, Greengard P, Yan Z (2004) Potentiation of NMDA receptor currents by dopamine D1 receptors in prefrontal cortex. Proc Natl Acad Sci USA 101:2596-2600.

Chen L, Bohanick JD, Nishihara M, Seamans JK, Yang CR (2007) Dopamine D1/5 receptor-mediated long-term potentiation of intrinsic excitability in rat prefrontal cortical neurons: $\mathrm{Ca}^{2+}$-dependent intracellular signaling. J Neurophysiol 97:2448-2464.

Dackis CA, Gold MS (1985) Bromocriptine as treatment of cocaine abuse. Lancet 1:1151-1152.

Dautzenberg FM, Hauger RL (2002) The CRF peptide family and their receptors: yet more partners discovered. Trends Pharmacol Sci 23:71-77.

De Martino B, Kumaran D, Seymour B, Dolan R (2006) Frames, biases, and rational decision-making in the human brain. Science 313:694-687.

Everitt BJ, Robbins TW (2005) Neural systems of reinforcement for drug addiction: from actions to habits to compulsion. Nat Neurosci 8:1481-1489.

Floresco SB, Tse MT (2007) Dopaminergic regulation of inhibitory and excitatory transmission in the basolateral amygdala-prefrontal cortical pathway. J Neurosci 27:2045-2057.

Franco R, Lluis C, Canela EI, Mallol J, Agnatoi L, Casadó V, Ciruela F, Ferré, 
S, Fuxe K (2007) Receptor-receptor interactions involving adenosine A1 or dopamine D1 receptors and accessory proteins. J Neural Transm 114:93-104.

Gabbott PLA, Warner TA, Busby SJ (2006) Amygdala input monosynaptically innervates parvalbumin immunoreactive local circuit neurons in rat medial prefrontal cortex. Neuroscience 139:1039-1048.

Gallagher JP, Orozco-Cabal LF, Liu J, Shinnick-Gallagher P (2008) Synaptic physiology of central CRH system. Eur J Pharmacol, in press.

Gao WJ, Krimer LS, Goldman-Rakic PS (2001) Presynaptic regulation of recurrent excitation by $\mathrm{D} 1$ receptors in prefrontal circuits. Proc Natl Acad Sci USA 98:295-300.

Goeders NE, Bienvenu OJ, De Sousa EB (1990) Chronic cocaine administration alters corticotropin-releasing factor receptors in the rat brain. Brain Res 531:322-328.

Grammatopoulos DK, Randeva H, Levine M, Kanellopoulou K, Hillhouse E (2001) Rat cerebral cortex corticotropin-releasing hormone receptors: evidence for receptor coupling to multiple G-proteins. J Neurochem 76:509-519.

Heinrichs SC, De Souza EB, Schulteis G, Lapsansky JL, Grigoriadis DE (2002) Brain penetrance, receptor occupancy and antistress in vivo efficacy of a small molecule corticotropin releasing factor type I receptor selective antagonist. Neuropsychopharmacology 27:194-202.

Henry B, Vale W, Markou A (2006) The effect of lateral septum corticotropin-releasing factor receptor 2 activation on anxiety is modulated by stress. J Neurosci 26:9142-9152.

Hillhouse EW, Grammatopoulos DK (2006) The molecular mechanisms underlying the regulation of the biological activity of corticotropinreleasing hormone receptors: implications for physiology and pathophysiology. Endocr Rev 27:260-286.

Hsu KS, Huang CC, Yang CH, Gean PW (1995) Presynaptic D2 dopaminergic receptors mediate inhibition of excitatory synaptic transmission in rat neostriatum. Brain Res 690:264-268.

Kelley AE (2004) Memory and addiction: shared neural circuitry and molecular mechanisms. Neuron 44:161-179.

Koob GF (1999) Stress, corticotropin-releasing factor, and drug addiction. Ann NY Acad Sci 897:445-460.

Krettek JE, Price JL (1977) Projections from the amygdaloid complex to the cerebral cortex and thalamus in the rat and cat. J Comp Neurol 172:687-721.

Krimer LS, Jakab RL, Goldman-Rakic PS (1997) Quantitative threedimensional analysis of the catecholaminergic innervation of identified neurons in the macaque prefrontal cortex. J Neurosci 17:7450-7461.

Ladera C, Godino MD, Martin R, Luján R, Shigemoto R, Cirule F, Torres M, Sánchez-Prieto J (2007) The coexistence of multiple receptors in a single nerve terminal provides evidence for pre-synaptic integration. J Neurochem 103:2314-2326.

Law-Tho D, Hirsch JC, Crepel F (1994) Dopamine modulation of synaptic transmission in rat prefrontal cortex: an in vitro electrophysiological study. Neurosci Res 21:151-160.

Leshner AI (1996) Understanding drug addiction: implications for treatment. Hosp Pract (Minneap) 31:47-49.

Levenson CW (2006) Regulation of the NMDA receptor: implications for neuropsychological development. Nutr Rev 64:428-432.

Liu J, Yu B, Neugebauer V, Grigoriadis DE, Rivier J, Vale WW, ShinnickGallagher P, Gallagher JP (2004) Corticotropin-releasing factor and urocortin I modulate excitatory glutamatergic synaptic transmission. J Neurosci 24:4020-4029.

Liu J, Yu B, Orozco-Cabal L, Grigoriadis DE, Rivier J, Vale WW, ShinnickGallagher P, Gallagher J (2005) Chronic cocaine administration switches corticotropin-releasing factor 2 receptor-mediated depression to facilitation of glutamatergic transmission in the lateral septum. J Neurosci 25:577-583.

Mair RD, Kauer JA (2006) Amphetamine depresses excitatory synaptic transmission at prefrontal cortical layer V synapses. Neuropharmacology 52:193-199.

Martin T, Torres M, Sanchez-Prieto J (2007) mGluR7 inhibits glutamate release through a PKC-independent decrease in the activity of $\mathrm{P} / \mathrm{Q}$ type $\mathrm{Ca} 2+$ channels and by diminishing cAMP in hippocampal nerve terminals. Eur J Neurosci 26:312-322.

Melis M, Pistis M, Perra S, Muntoni AL, Pillolla G, Gessa GL (2004) Endocannabinoids mediate presynaptic inhibition of glutamatergic transmis- sion in rat ventral tegmental area dopamine neurons through activation of CB1 receptors. J Neurosci 24:53-62.

Merchenthaler I (1984) Corticotropin releasing factor (CRF)-like immunoreactivity in the rat central nervous system. Extrahypothalamic distribution. Peptides 5 [Suppl 1]:53-69.

Merlo PE, Lorang M, Yeganeh M, Rodriguez de FF, Raber J, Koob GF, Weiss F (1995) Increase of extracellular corticotropin-releasing factor-like immunoreactivity levels in the amygdala of awake rats during restraint stress and ethanol withdrawal as measured by microdialysis. J Neurosci 15:5439-5447.

Milan-Lobo L, Ruentzler D, Bonci A, Freissmuth M, Sitte HH (2006) Visualizing the membrane mobility of corticotrophin-releasing-factor-type 2 receptors (CRF2-R) by fluorescence microscopy. Soc Neurosci Abstr 32:726.9.

Missale C, Nash SR, Robinson SW, Jaber M, Caron MG (1998) Dopamine receptors: from structure to function. Physiol Rev 78:189-225.

Momiyama T, Sim JA, Brown DA (1996) Dopamine D-like receptormediated presynaptic inhibition of excitatory transmission onto rat magnocellular basal forebrain neurones. J Physiol (Lond) 495:97-106.

Morin SM, Ling N, Liu XJ, Kahl SD, Gehlert DR (1999) Differential distribution of urocortin- and corticotropin-releasing factor-like immunoreactivities in the rat brain. Neuroscience 92:281-291.

Nasif FJ, Hu XT, White FJ (2005a) Repeated cocaine administration increases voltage-sensitive calcium currents in response to membrane depolarization in medial prefrontal cortex pyramidal neurons. J Neurosci 25:3674-3679.

Nasif FJ, Sidiropoulou K, Hu XT, White FJ (2005b) Repeated cocaine administration increases membrane excitability of pyramidal neurons in the rat medial prefrontal cortex. J Pharmacol Exp Ther 312:1305-1313.

Ohno-Shosaku T, Shosaku J, Tsubokawa H, Kano M (2002) Cooperative endocannabinoid production by neuronal depolarization and group I metabotropic glutamate receptor activation. Eur J Neurosci 15:953-961.

Onn SP, Wang X-B, Lin M, Grace AA (2006) Dopamine D1 and D4 receptor subtypes differentially modulate recurrent excitatory synapses in prefrontal cortical pyramidal neurons. Neuropsychopharmacology 31:318-338.

Orozco-Cabal L, Pollandt S, Liu J, Vergara L, Shinnick-Gallagher P, Gallagher JP (2006a) A novel rat medial prefrontal cortical slice preparation to investigate synaptic transmission from amygdala to layer $\mathrm{V}$ prelimbic pyramidal neurons. J Neurosci Methods 151:148-158.

Orozco-Cabal L, Pollandt S, Liu J, Shinnick-Gallagher P, Gallagher JP (2006b) Regulation of synaptic transmission by CRF receptors. Rev Neurosci 17:279-307.

Paspalas CD, Goldman-Rakic PS (2004) Microdomains for dopamine volume neurotransmission in primate prefrontal cortex. J Neurosci 24:5292-5300.

Paspalas CD, Goldman-Rakic PS (2005) Presynaptic $\mathrm{D}_{1}$ dopamine receptors in primate prefrontal cortex: target-specific expression in the glutamatergic synapse. J Neurosci 25:1260-1267.

Paxinos G, Watson C (1998) The rat brain. Orlando, FL: Harcourt.

Pollandt S, Liu J, Orozco-Cabal L, Grigoriadis DE, Vale WW, Gallagher JP, Shinnick-Gallagher P (2006) Cocaine withdrawal enhances long-term potentiation induced by corticotropin-releasing factor at central amygdala glutamatergic synapses via CRF, NMDA receptors and PKA. Eur J Neurosci 24:1733-1743.

Ragozzino ME (2002) The effects of dopamine D(1) receptor blockade in the prelimbic-infralimbic areas on behavioral flexibility. Learn Mem 9:18-28.

Rice DP (1999) Economic costs of substance abuse, 1995. Proc Assoc Am Phys 111:119-125.

Richter RM, Pich EM, Koob GF, Weiss F (1995) Sensitization of cocainestimulated increase in extracellular levels of corticotropin-releasing factor from the rat amygdala after repeated administration as determined by intracranial microdialysis. Neurosci Lett 187:169-172.

Richter RM, Weiss F (1999) In vivo CRF release in rat amygdala is increased during cocaine withdrawal in self-administering rats. Synapse 32:254-261.

Rivier J, Gulyas J, Kirby D, Low W, Perrin MH, Kunitake K, DiGruccio M, Vaughan J, Reubi J-C, Waser B, Koerber SC, Martinez V, Wang L, Tache Y, Vale W (2002) Potent and long-acting corticotropin releasing factor (CRF) receptor 2 peptide competitive antagonists. J Med Chem 45:4737-4747. 
Schoenbaum G, Roesch MR, Stalnaker TA (2006) Orbitofrontal cortex, decision-making and drug addiction. Trends Neurosci 29:116-124.

Seamans JK, Durstewitz D, Christie BR, Stevens CF, Sejnowski TJ (2001a) Dopamine D1/D5 receptor modulation of excitatory synaptic inputs to layer V prefrontal cortex neurons. Proc Natl Acad Sci USA 98:301-306.

Seamans JK, Gorelova N, Durstewitz D, Yang CR (2001b) Bidirectional dopamine modulation of GABAergic inhibition in prefrontal cortical pyramidal neurons. J Neurosci 21:3628-3638.

Seamans JK, Yang CR (2004) The principal features and mechanisms of dopamine modulation in the prefrontal cortex. Prog Neurobiol 74:1-58.

Smiley JF, Levey AI, Ciliax BJ, Goldman-Rakic PS (1994) D1 dopamine receptor immunoreactivity in human and monkey cerebral cortex: predominant and extrasynaptic localization in dendritic spines. Proc Natl Acad Sci USA 91:5720-5724.

Sorg BA, Davidson DL, Kalivas PW, Prasad BM (1997) Repeated daily cocaine alters subsequent cocaine-induced increase of extracellular dopamine in the medial prefrontal cortex. J Pharmacol Exp Ther 281:54-61.

Stalnaker TA, Roesch MR, Franz TM, Calu DJ, Singh T, Schoenbaum G (2007) Cocaine-induced decision-making deficits are mediated by miscoding in basolateral amygdala. Nat Neurosci 10:949-951.

Stanwood GD, Levitt P (2007) Prenatal exposure to cocaine produces unique developmental and long-term adaptive changes in dopamine $\mathrm{D}_{1}$ receptor activity. J Neurosci 27:152-157.

Steketee JD (2005) Cortical mechanisms of cocaine sensitization. Crit Rev Neurobiol 17:69-86.

Trantham H, Szumlinski KK, McFarland K, Kalivas PW, Lavin A (2002) Repeated cocaine administration alters the electrophysiological properties of prefrontal cortical neurons. Neuroscience 113:749-753.

Tseng KY, O’Donnell P (2004) Dopamine-glutamate interactions controlling prefrontal cortical pyramidal cell excitability involve multiple signaling mechanisms. J Neurosci 24:5131-5139.

Ungless MA, Singh V, Crowder TL, Yaka R, Ron D, Bonci A (2003) Corticotropin-releasing factor requires $\mathrm{CRF}$ binding protein to potentiate NMDA receptors via CRF receptor 2 in dopamine neurons. Neuron 39:401-407.

Urban NN, Gonzalez-Burgos G, Henze DA, Lewis DA, Barrionuevo G (2002) Selective reduction by dopamine of excitatory synaptic inputs to pyramidal neurons in primate prefrontal cortex. J Physiol (Lond) 539:707-712.

Vale W, Spiess J, Rivier C, Rivier J (1981) Characterization of a 41-residue ovine hypothalamic peptide that stimulates secretion of corticotropin and beta-endorphin. Science 213:1394-1397.

Volkow ND, Wang GJ, Fowler JS, Logan J, Hitzemann R, Gatley SJ, MacGregor RR, Wolf AP (1996) Cocaine uptake is decreased in the brain of detoxified cocaine abusers. Neuropsychopharmacology 14:159-168.

Wang J, O'Donnell P (2001) D(1) dopamine receptors potentiate NMDAmediated excitability increase in layer $\mathrm{V}$ prefrontal cortical pyramidal neurons. Cereb Cortex 11:452-462.

Williams JM, Steketee JD (2005) Time-dependent effects of repeated cocaine administration on dopamine transmission in the medial frontal cortex. Neuropharmacology 48:51-61.

Winston JS, Gottfried JA, Kilner JM, Dolan RJ (2005) Integrated neural representations of odor intensity and affective valence in human amygdala. J Neurosci 25:8903-8907.

Yamada K, Yu B, Gallagher JP (1999) Different subtypes of GABA $A_{B}$ receptors are present at pre- and postsynaptic sites within the rat dorsolateral septal nucleus. J Neurophysiol 81:2875-2883.

Yan XX, Baram TZ, Gerth A, Schultz L, Ribak CE (1998) Co-localization of corticotropin-releasing hormone with glutatamate decarboxylase and calcium-binding proteins in infant rat neocortical interneurons. Exp Brain Res 123:334-340.

Yang CR, Seamans JK, Gorelova N (1996) Electrophysiological and morphological properties of layers V-VI principal pyramidal cells in rat prefrontal cortex in vitro. J Neurosci 16:1904-1921.

Zheng P, Zhang XX, Bunney BS, Shi WX (1999) Opposite modulation of cortical $N$-methyl-D-aspartate receptor-mediated responses by low and high concentrations of dopamine. Neuroscience 91:527-535.

Zhou FM, Hablitz JJ (1999) Dopamine modulation of membrane and synaptic properties of interneurons in rat cerebral cortex. J Neurophysiol 81:967-976.

Zorrilla EP, Valdez GR, Weiss F (2001) Changes in levels of regional CRF-like-immunoreactivity and plasma corticosterone during protracted drug withdrawal in dependent rats. Psychopharmacology (Berl) 158:374-381. 